Canadian Science Publishing

Canadian Journal of Earth Sciences Revue canadienne des sciences de la Terre

The Devonian Horn River Group and the basal Imperial Formation of the central Mackenzie Plain, N.W.T., Canada: Multiproxy stratigraphic framework of a black shale basin

\begin{tabular}{|r|l|}
\hline Journal: & Canadian Journal of Earth Sciences \\
\hline Manuscript ID & cjes-2016-0096.R2 \\
\hline Manuscript Type: & Article \\
\hline Date Submitted by the Author: & $24-$ Oct-2016 \\
\hline Complete List of Authors: & $\begin{array}{l}\text { Kabanov, Pavel; Natural Resources Canada, Geological Survey of Canada } \\
\text { Gouwy, Sofie Annie; Natural Resources Canada, Geological Survey of } \\
\text { Canada }\end{array}$ \\
\hline Keyword: & $\begin{array}{l}\text { Devonian, Canol shale play, Lithostratigraphy, Chemostratigraphy, } \\
\text { Conodonts }\end{array}$ \\
\hline
\end{tabular}


The Devonian Horn River Group and the basal Imperial Formation of the central Mackenzie Plain, N.W.T., Canada: Multiproxy stratigraphic framework of a blackshale basin

${ }^{1}$ Kabanov, P. and ${ }^{2}$ Gouwy, S.A.

${ }^{1}$ Geological Survey of Canada, 3303, $33^{\text {rd }}$ street NW, Calgary, T2L2A7.

Pavel.Kabanov@canada.ca

${ }^{2}$ Geological Survey of Canada, 3303, $33^{\text {rd }}$ street NW, Calgary, T2L2A7.

Sofie.Gouwy@canada.ca

Corresponding author: Pavel Kabanov, Geological Survey of Canada, 3303, 33rd street

NW, Calgary, T2L2A7

Tel: $1-403-292-7164$

Fax: 1-403-292-5377

Pavel.Kabanov@,canada.ca 


\title{
The Devonian Horn River Group and the basal Imperial Formation of the central Mackenzie Plain, N.W.T., Canada: Multiproxy stratigraphic framework of a black- shale basin
}

${ }^{1}$ Kabanov, P. and ${ }^{2}$ Gouwy, S.A.

\begin{abstract}
This study proposes six new lithostratigraphic units and redefines two others within the Horn River Group (HRG), a shale-dominated succession recently prospected for shale hydrocarbons. Its lower Hare Indian Formation rests on a drowning unconformity. In the SOB area (the area between Norman Wells and the Keele tectonic zone), this formation consists of the Bluefish black-shale, Francis Creek grey-shale, and Prohibition Creek blackshale members. The latter two are lateral equivalents of the grey -shale Bell Creek Member (updated definition) in the northern part of the study area. The overlying Canol Formation in the SOB area is divided into the Vermillion Creek and Dodo Canyon members. The Prohibition - Dodo Canyon package is $\geq 100 \mathrm{~m}$ thick and composed of brittle siliceous mudrocks with median $\mathrm{SiO}_{2} 68-79 \%, \mathrm{Al}_{2} \mathrm{O}_{3} 6-9 \%$, varying amount of calcite and dolomite, and type I-II kerogen with median TOC 4.5\%. The thin Canol Formation blanketing Kee Scarp carbonate banks is identified as its Dodo Canyon Member. The latter is a "sweet bed" for fracking with median $\mathrm{SiO}_{2} 75-79 \%$, TOC 5.1\%, and trace-metal signatures
\end{abstract}


indicating strongest anoxia in the section. The Mirror Lake Member in the base of the overlying Imperial Formation consists of soft illite-rich grey shales with minor siderite and dolomite. The overlying Loon Creek Member is composed of Canol-like black shale facies in its basal part and less organic-rich, lighter-colored shales and siltstones above. The Loon Creek Member is partly coeval with an overlying succession of sandstones and siltstones of the Canyon Member in its updated definition. Conodont data do not indicate significant time gaps between lithostratigraphic units. The majority of standard conodont zones from the uppermost Eifelian (ensensis Zone) up to the middle Frasnian (punctata Zone) are recognized. Assemblages of the hemiansatus and semialternans/latifossatus zones are missing probably due to scarcity of conodont samples. The base of the HRG approximates the Eifelian/Givetian boundary, and the Hare Indian Formation is mostly Givetian. The Vermillion Creek Member spans the Givetian-Frasnian boundary. In places where thick Kee Scarp carbonates aggrade on thick sections of the Bell Creek Member, the Kee Scarp Canol contact is found within the transitans Zone and the Middle Frasnian punctata Zone conodont assemblage is found in the basal part of the Dodo Canyon Member. The main part of the Dodo Canyon Member and basal beds of the Imperial Formation remain undated.

Key words: Devonian, Canol shale play, lithostratigraphy, chemostratigraphy, conodonts.

\section{INTRODUCTION}

The Givetian - Frasnian Horn River Group (HRG) located in the Mackenzie Corridor (Fig. 1) is dominated by shales with important black shale units that locally exceed $200 \mathrm{~m}$ in thickness (Pyle and Gal, 2016; Kabanov et al. 2016a, 2016b). These black shales host major hydrocarbon resources of the Northwest Territories occurring within and locally 
beyond the oil window (Hamblin 2006; Hayes 2011; Pyle et al. 2015). These frontier unconventional resources, referred to as the "Canol Shale Play", have recently seen significant exploration activity in an area covering 1.28 million hectares in the Mackenzie Valley to the northwest and south of Norman Wells (AANDC 2014, 2015).

The subsurface stratigraphy of the HRG in the study area was developed decades ago when black shale units were not considered economical (Fig. 2; Tassonyi 1969; Pugh 1983, 1993), and focus was directed to the Ramparts limestone, which host one giant conventional oilfield at Norman Wells. The stratigraphy of the Ramparts Formation, in particular the oil-producing carbonate bank at Norman Wells, was developed in remarkable detail at the level of meter-scale sedimentary cycles/parasequences (Muir et al. 1984; Muir and Dixon 1985; Muir 1988; Yose et al. 2001). Unlike the Ramparts limestone, shale units have not had representative core coverage until recently, and the previous geological assessment utilized the preexisting stratigraphic framework with partially revised formation tops and one new member name proposed (Gal et al. 2009; Gal and Pyle 2012; Pyle et al. 2014; Pyle and Gal, 2016).

The ongoing Mackenzie Project of the GEM-2 Program includes the study of the Devonian stratigraphic framework. Data from exploration wells drilled in 2012-2013, along with revision of older materials, are leading to new insights into lithostratigraphy including visual, well log, lithogeochemical, and organic-matter characterization, as well as updates in their biostratigraphy (Kabanov 2015; Kabanov et al. 2015; Kabanov et al. 2016a). This paper describes preexisting and newly proposed subdivisions of the HRG with the goal of improving the practical stratigraphic resolution for hydrocarbon exploration and academic studies. 


\section{REGIONAL GEOLOGY}

The study area is located within NTS map areas $96 \mathrm{C}, 96 \mathrm{D}$, and $96 \mathrm{E}$ of the central part of Mackenzie River Corridor, including the Mackenzie Valley, the eastern flank of the Mackenzie Mountains, and the western flank of the Norman Range (Fig. 1). Mackenzie River Corridor refers to a geographic area defined by the drainage system of the Mackenzie River and extending from southern NWT boundary northward to the limits of the Mackenzie Delta/Beaufort region (Hannigan et al. 2011).

\section{Geotectonic and paleogeographic context}

The Mackenzie Corridor includes two major geological provinces, the relatively undeformed Interior Platform and the Laramide (Late Cretaceous-Tertiary) fold-andthrust belt of the eastern Cordillera (Hannigan et al. 2011; Morrow 2012). The Devonian facies architecture and the formal stratigraphy of both provinces are equivalent (Morrow 2012). Structurally the Mackenzie Valley occupies a thrust sheet complex soling into a detachment within the salt of the Cambrian Saline River Formation. The thrusting may be active at present and transferring strain from the main Cordilleran system northeastward (Lawton and Isaak, 2005; Hadlari, 2015). The Norman Range is the topographic expression of the main thrust fault, leaving most of the studied sections within the hanging wall and only four wells in the footwall (Fig. 1).

Before the Jurassic, the study area was situated on the passive continental margin. The black shale basin of the HRG is traced along the Laramide foreland-basin trend of the Mackenzie and Richardson Mountains, from the Horn River Basin in northeastern British 
Columbia to the Mackenzie River delta, and records the spread of dysoxic-anoxic waters and the influx of fine siliciclastics upon the shallow-water carbonate shelf of the passive continental margin (Morrow and Geldsetzer 1988; Morrow 2012). Based on apatite fission track and vitrinite reflectance signatures from East McKay I-77 well, the Devonian succession in the study area became deeply buried by Late Triassic - Early Jurassic time and exhumed by mid-Cretaceous time allowing complete removal of postDevonian rocks prior to mid-Cretaceous - Cenozoic foreland basin subsidence (Issler et al. 2005; Hadlari 2015).

\section{Stratigraphic nomenclature}

The name "Horn River shale" was originally given by Whittaker (1922) based on a low black shale outcrop located southwest of Great Slave Lake $\left(61^{\circ} 44^{\prime} \mathrm{N}, 117^{\circ} 45^{\prime} \mathrm{W}\right)$, and its usage at the formation level was first applied to a belt of strata from northeastern British Columbia to Great Slave Lake in NWT, that is well to the south of the study area (review in Pyle and Gal, 2016). After subsequent redefinitions and various applications, the Horn River Formation has been elevated to group status encompassing Givetian-Frasnian (Middle-Upper Devonian) shale-dominated strata, sandwiched between the Hume/Nahanni/Keg River limestones and the siliciclastics of the Imperial Formation and its southern equivalents (Pugh 1983, 1993; Williams 1983; Morrow 2012). The HRG, characterized by overall dominance of black basinal shales, is traced longitudinally from the Horn River Basin of northeastern B.C. to the Mackenzie Delta area and from its eastern erosional edge to the west across the Mackenzie and Richardson mountains (Williams 1983; Morrow 2012). The nomenclature of lithostratigraphic units included in the group drastically changes across $63^{\circ}$ latitude and bears unresolved correlation issues 
reviewed by Williams (1983), Meijer Drees (1993), Morrow (2012), and Pyle and Gal (2016). In the study area the HRG includes the Hare Indian, Ramparts, and Canol formations, and their member subdivisions (Fig. 2) will be discussed in detail below.

Bundling of the Hare Indian, Ramparts, and Canol formations into the HRG was historically conflicted by the concept of a sub-Canol unconformity. This unconformity, supported by the then-available biostratigraphy (Hume and Link 1945; Bassett 1961; Bassett and Stout 1967; Aitken et al. 1982; Norris 1985, 1997), sought to explain the sharp thickness fluctuations and restricted spatial distribution of the Hare Indian and Ramparts formations as a result of regional erosion prior to Canol shale deposition. This "Late Middle Devonian unconformity" (Hume and Link 1945) appeared in successive formation charts including most recent ones (Morrow 2012; Rocheleau and Fiess 2014). Another school of thought favoring a conformable contact between the Canol and underlying formations and promoting recognition of the HRG to the north of $63^{\circ}$ (Williams 1983; Pugh 1983) has gained ground with increasing awareness of conformable contacts and partial facies transitions between the Ramparts and the lower Canol formations (Muir and Dixon 1985; Muir 1988). Moreover, available data on conodont distribution do not support the concept of a pre-Canol hiatus (Kabanov et al. $2016 a)$

\section{MATERIALS AND METHODS}

\section{Measured sections}

This study was developed from examination of continuous cores from the recently drilled exploration wells Little Bear N-09, Loon Creek O-06, Mirror Lake N-20, and East 
Mackay I-78 (Figs. 1 and 3). This material was supplemented by shorter cored sections from several historical wells that appeared in multiple publications: Canyon Creek no. 1(G-51) and no. 2 (J-20), Maida Creek G-56, Morrow Creek J-71, Mackenzie River \# 4 (E-27), and Norman Wells P32X (M-46). In total, $706 \mathrm{~m}$ of cores from the HRG and from beds immediately below and above were measured. Two outcrop sections measured by the first author are Prohibition Creek and Francis Creek (Fig. 1). Illustrated descriptions of cored and outcrop sections are available in Kabanov (2015) and Kabanov et al. $(2016 a)$.

\section{Lithogeochemistry and pyrolysis}

Cores from the Little Bear N-09 and Loon Creek O-06 wells were sampled every $50 \mathrm{~cm}$ for ICP-MS geochemistry and Rock-Eval 6 pyrolysis. The total of 706 samples from these two wells were run for elemental composition at Acme Analytical Laboratories in Vancouver, BC, including whole-rock fusion (33 major and rare earth elements), aqua regia digestion (14 elements), and LECO combustion for total sulphur and carbon. The same samples were run for Rock-Eval 6 pyrolysis-combustion at the Organic Petrology and Geochemistry Laboratory in GSC (Calgary). This analytical bundle is identical to that retrieved by NTGS from outcrops and old well samples during their Mackenzie Plain Petroleum Project (Pyle et al. 2011, 2014, 2015; Pyle and Gal 2012, 2013; Gal and Pyle 2012), ensuring data compatibility. The complete description of Rock-Eval 6 method is available in Behar et al. (2001). Geochemical and pyrolysis data from Little Bear N-09 and Loon Creek O-06 wells, along with more detailed method reviews, are available in (Kabanov et al. 2015, 2016a). 


\title{
Geophysical logs
}

The borehole logs used for stratigraphic correlation (Figs. 3-6) include spectral gammaray logs (SGR) from recently drilled wells, total gamma (GR) from older wells, sonic and resistivity logs. Resistivity logs are critical for correlation with borehole sections from 1940s (Figs. 4-6). Deep-induction and laterolog curves from newer wells show a robust match to unfocussed historical resistivity logs generated during Camp Canol exploration activity and utilized by Tassonyi (1969) for his correlations.

SGR logs appear to be most useful to divide the mudrock-dominated succession of the HRG into clay-rich (high K and Th) and clay-lean (low K-Th, high U) packages. SGR logs were also acquired with RC-230 BGO handheld scintillometer from outcrops and older cores. SGR logging of outcrops at $0.5 \mathrm{~m}$ steps is the key for correlation with the subsurface (Kabanov et al. 2016a). SGR logs are represented by two frequently used proxies, the uranium-stripped gamma ray, also known as clay or computed gamma ray (CGR) and the total gamma ray indexed as SGR (Ellis and Singer 2008). The contribution of $\mathrm{K}, \mathrm{U}$, and $\mathrm{Th}$ series to $\mathrm{SGR}$ is described by the formula: GR[API] = $4 \mathrm{Th}[\mathrm{ppm}]+8 \mathrm{U}[\mathrm{ppm}]+16 \mathrm{~K}[\%]$ (Ellis and Singer 2008), deriving CGR[API] $=$ $4 \mathrm{Th}[\mathrm{ppm}]+16 \mathrm{~K}[\%]$

\section{LITHOSTRATIGRAPHIC UNITS AND THEIR CONTACTS}

\author{
Hume/Bluefish contact
}

Description 
This contact separates the typical upper Hume facies of bioturbated, richly fossiliferous limestone containing a diverse benthic fauna from black calcareous laminated shales of the Bluefish Member. It was repeatedly described as either abrupt but conformable (Bassett 1961; Tassonyi 1969; Pugh 1983, 1993) or disconformable (Norris 1968, 1997; Gal et al. 2009), but the amount of erosional truncation was interpreted as negligible, not exceeding a few centimeters (Pyle et al. 2014). At the outcrop scale, the Hume top appears table flat unless tectonically displaced and the contrasting lithologies below and above the surface make it an excellent datum in regional surface and subsurface stratigraphy.

The Hume/Bluefish contact has been measured in three cores from Canol Shale exploration wells and accessed in the Francis Creek outcrop (Fig. 7). The coralstromatoporoid facies of the Hume Formation occurs in direct contact with the Bluefish shale only in core from East MacKay I-78 where the Hume limestone has a rugged, apparently dissolved top with deep $(8 \mathrm{~cm})$ solution pockets filled with black shale; the upper few decimeters below the top are chertified. In Loon Creek O-06 and Little Bear N-09, the "typical Hume" limestone with diverse corals and stromatoporoids is overlain by an argillaceous micritic limestone (calcimudstone to brachiopod packstone) with shale interbeds. This unit, $1.6 \mathrm{~m}$ thick in Loon Creek O-06 and 0.5 m thick in Little Bear N-09, is referred to as the uppermost Hume bed. It has been reported from many outcrop localities (Gal et al. 2009) including Powell Creek where it is $2.6 \mathrm{~m}$ thick (Pyle and Gal 2012) and Francis Creek (0.75 m; Kabanov et al. 2016a). The base of this unitappears conformable in all measured sections. In Little Bear N-09, this unit is composed of bioclastic packstone and wackestone with abundant brachiopods, some bryozoans and 
infrequent pachyporid corals; it is vigorously bioturbated with overprinted ichnofossil generations, including the late-phase upright borings or firmground burrows (Fig. 7B-D). The top of the Hume Formation in that core is a hardground: it is rugged, overprinted by pressure solution, and macrofossils immediately under the top are poorly preserved due to an early diagenetic chemical corrosion and chertification (Appendix 9 in Kabanov et al. 2016a). In Loon Creek O-06, the hardground is absent. The vigorously bioturbated facies similar to the one described above is found in the basal $40 \mathrm{~cm}$, and grades upwards into a massive very dark grey calcimudstone containing common tentaculitids and partly retaining sedimentary lamination in the uppermost $30 \mathrm{~cm}$. The top of this dark calcimudstone is sharp and smoothly undulating (Appendix 6 in Kabanov et al. 2016a). At Francis Creek, the upper contact of the Hume Formation is similar to that in Loon Creek O-06, although the level of vigorous bioturbation was not observed (Fig. 7D).

The base of the Bluefish Member is placed at the base of the matrix-poor argillaceous bioclastic limestone (packstones, grainstones and rudstones) composed of a mixture of brachiopod fragments, pelmatozoan ossicles, and tentaculitids (Fig. 7A). Such limestone, only 8-20 cm thick, was found in all studied sections. It differs from the uppermost Hume calcimudstone by its compactional fissility (the uppermost Hume bed is uncompacted), the rock-forming abundance of tentaculitids, the weaker bioturbation with the bioturbation index (BI) ranging from 1 to 3 (Taylor et al. 2003), and the lack of micritic carbonate matrix. The hardground in Little Bear N-09 is overlain by a tentaculitid crosslaminated grainstone with no benthic fossils detected. Abundance of brachiopod valves found in this bed in other sections favors its correlation with the brachiopod coquinas dominated by Leiorhynchus castanea (Meek) described in outcrops to the northwest of 
the study area as a basal bed of the Bluefish Member (Norris 1985, 1997). Upwards the basal Bluefish limestone grades into finely laminated calcareous black shales (Kabanov et al. 2016a), which is the main Bluefish facies.

The uppermost Hume fossil assemblage is markedly different from fossils in the underlying Hume limestone: it has no stromatoporoids, only sporadic corals, but significant numbers of tentaculitids, and shows a distinct change in the brachiopod assemblage including introduction of phosphatic inarticulates Lingula sp. and Orbiculoidea sp. (Lenz and Pedder 1972). These changes were noted in several sections (Kabanov et al. 2016a). The basal Bluefish fossil assemblage is different from the topmost Hume assemblage only by aa shift to dominance of pelagic tentaculitids over benthic forms (Lenz and Pedder 1972) and rapid decline of bioturbation to zero in the transition to the overlying laminated shale (Kabanov et al. 2016a). Tentaculitids in the entire HRG are mostly represented by small $(<2 \mathrm{~mm})$ dacryoconarid forms, which is typical for Middle Devonian basins.

\section{Interpretation}

Available data indicate a condensed (less than $2 \mathrm{~m}$ thick in most sections) deepeningupward facies succession with a two-step drowning phase recorded in the topmost Hume limestone and the basal Bluefish limestone. These twosteps are separated by a sharp surface with laterally changing character: a well-developed hardground where the uppermost Hume limestone is thin or absent on inferred seafloor highs and a planar surface of storm-wave scouring where the uppermost Hume limestone is relatively thick in areas of paleotopographic lows, in still oxygenated quiet-water environment as evidenced by bioturbation and in-situ benthic fossils. As seen in the Loon Creek O-06 
core, the abrupt Hume-Bluefish contact represents a two-fold change: (1) shutoff of carbonate mud production and (2) short-term spread of high-energy tempestite regime where storm waves could recycle surficial sediments into amalgamated coquinas of the basal Bluefish limestone. The possibility of downslope transport of skeletal material by density currents is discredited by the table flat character of the Hume top across the central and northern Mackenzie Corridor. In any case, storm scouring could hardly be significant as no intraclasts or pebbles are reported from the basal Bluefish bed. Gradation to undisturbed laminated shale in top of the basal Bluefish limestone records further drowning below the reach of storm scouring, final retreat of the benthic carbonate factory, and spread of terrigenous mud deposition.

Drowning surfaces such as the Hume/Bluefish contact are known as drowning unconformities (Schlager 1981; Catuneanu 2006; Godet 2013), also called Type 3 sequence boundaries (Schlager 1999). Such surfaces are specific to carbonate sedimentary factories (Catuneanu 2006) that can be suppressed or switched off by a combination of factors such as sediment starvation, sea level rise, bottom water cooling, eutrophication, pollution by muds, and/or stratification of the water column (Schlager 2003; Mutti and Hallock 2003). There is a high probability for the Hume/Bluefish drowning unconformity represents the global Kačak event correlated to the uppermost part of the Eifelian (ensensis Zone) (House 2002).

\section{Hare Indian Formation}

The name "Hare Indian River shale" was first applied by Kindle and Bosworth (1921) to shales underlying the Ramparts limestone at the lower end of the Rampart Gorge in the 
Fort Good Hope area. On the basis of this original use, the mappable Hare Indian Formation was defined by Bassett (1961). The formation is composed of greenish grey slightly calcareous shales with some limestone interbeds. It contains some benthic macrofossils along with pelagic tentaculitids and acritarchs (spores in early works), and has a basal dark bituminous interval (Bassett 1961) named a spore-bearing member by Tassonyi (1969). Tassonyi (1969) also considered applying the pre-existent name Bluefish Member after resolving then-existing issues with toponymy and a type section. The thickness of the typical Hare Indian Formation was indicated to vary between 152 and 183 m (Bassett 1961), which was generally confirmed by the subsurface study (Tassonyi 1969). Regional geologists referred to the main upper grey shale part of the Hare Indian Formation as an informal grey shale member until a recent proposal to name it the Bell Creek Member (Pyle et al. 2014). Basset (1961) indicated that the Hare Indian Formation grades southward into dark grey partly bituminous shale past latitude $65^{\circ} 20^{\prime} \mathrm{N}$, and further subsurface correlations led to recognition of an informal black shale member as a lateral facies equivalent of the grey shale member (Pugh 1993). Thickness variations and isopach maps of the Hare Indian Formation, its members and overlying units within the study area are discussed in Kabanov et al. (2016b). Earlier versions of isopach maps in the study area have been published by Pugh (1983, 1993); Gal et al. (2009) and Pyle et al. (2014).

\section{Bluefish Member}

The Bluefish Member has two proposed type sections: Powell Creek, UTM 511225E, 7239972N (Pugh 1983) and Mountain River, UTM 518945E, 7235192N (Pyle et al., 2014). The latter is favored because of better exposure (Pyle et al. 2014). The Bluefish 
Member of the study area has received comprehensive description in a number of publications (Tassonyi 1969; Pugh 1983; Gal et al. 2009; Pyle et al. 2014), and data from new sections do not bring in significant novelty (Kabanov et al. 2016a). In new cores, the Bluefish Member shows the typical laminar black calcareous shales frequently interbedded with thin $(0.1-10 \mathrm{~mm})$ tentaculitid-rich limestone laminae. The upper onehalf of the member is less calcareous, contains pyritized sponge spicules and abundant organic-walled acritarchs (algocysts of Tassonyi 1969) identified as Leiosphaeridia and Tasmanites s.l. (Pugh 1983). Benthic fossils are very rare except in the basal brachiopod coquina, and they include small phosphatic lingulate brachiopods reported from the basal, middle, and uppermost parts of the Bluefish Member (Lenz and Pedder 1972; Kabanov et al. 2016a). The basal part (approximately $0.6 \mathrm{~m}$ ) of the member is rich in macrofossils with a diverse assemblage of small brachiopods named the castanea fauna after Leiorhynchus castanea (Meek) (Norris 1968, 1985).

A marker cone-in-cone fibrous diagenetic limestone (marker fibrous calcite bed; Mackenzie 1972) is traced at a rather constant distance above the base: $2.7 \mathrm{~m}$ at Francis Creek, $2.6 \mathrm{~m}$ in Loon Creek O-06 well, and $2.5 \mathrm{~m}$ in Little Bear N-09 well. The East MacKay I-78 shows four levels of cone-in-cone limestone, the thickest one at 1941.951942.2 $\mathrm{m}$ (14.5 m above the Hume top), and the lower cone-in-cone limestone, only 10 cm thick, occurs at $1953.25 \mathrm{~m} \mathrm{MD}$, at $3.45 \mathrm{~m}$ above the base.

\section{Bell Creek Member}

The name Bell Creek Member was proposed by Pyle et al. (2014) as an informal replacement for the grey shale and the black shale informal members of the Hare Indian Formation (Pugh 1993). The Bell Creek Member is typified by the original stratotype at 
Ramparts Gorge (Kindle and Bosworth 1921) and subsequently named reference sections at Powell Creek (Pugh 1983), Mountain River tributary, and Bell Creek (Pyle et al. 2014). The latter section, parental to the unit name, is located at UTM 501061E, 7240021N (Pyle et al. 2014). We propose to formalize the Bell Creek Member and restrict its usage to typical thick sections of greenish grey, variously bioturbated calcareous and fossiliferous shales composing the spatially restricted "shale banks" sensu Muir et al. (1984) and Muir (1988). Recent Canol Shale exploration wells are located in the SOB area and do not intersect the Bell Creek Member in its updated definition. Comprehensive descriptions can be found elsewhere (Bassett 1961; Tassonyi 1969; Norris 1968, 1985; Pugh 1983; Muir 1988; Gal et al. 2009; Pyle et al. 2014). Reasoning for restricting the usage of the Bell Creek Member lies in the difficulty to separately map the black shale equivalent of the typical Bell Creek Member and the overlying Canol Formation (Pugh 1983). The Bell Creek Member contains a mixture of benthic and pelagic fossils with brachiopods, conodonts, tentaculitids and ammonoids; and corals in the uppermost part (Lenz and Pedder 1972; Norris 1968, 1985).

\section{Francis Creek Member}

The newly proposed Francis Creek and Prohibition Creek members replace the black shale member of Pugh (1993) and the "atypical Bell Creek member" of Pyle et al. (2014). The Francis Creek Member receives its name from a left-bank outcrop (looking downstream) at Francis Creek measured in 2015 (field station 15KOA006, UTM 9N 622113E, 7237921N; Kabanov et al. 2016a).

The new member is fissile grey shale with minor very fine-grained $(62-125 \mu \mathrm{m}$ in Udden-Wentworth scale) muddy sandstones and siltstones, with gradational upper and 
lower contacts. The unit is notably rich in expandable clays imparting a recessive weathered character in outcrops (Kabanov et al. 2016a). In non-weathered core sections, silty shales and siltstones of this unit show masses of pyritized tablets on some fissility planes (pyritized acritarchs; Fig. 8G). Pyrite encrustations on acritarchs are even and very fine-grained. This taphonomic signature makes the Francis Creek Member distinct from the underlying Bluefish Member where acritarchs are mostly devoid of pyrite encrustations. Bioturbation is mostly lacking, and the rock retains sedimentary lamination; collapsed Chondrites burrows were encountered once in the core (Kabanov et al. 2016a). The newly defined Francis Creek Member differs from the typical Bell Creek Member by lack of calcareous material, benthic shelly fossils, and any significant bioturbation. The member is identified in two measured outcrops (Kabanov et al. 2016a) and 17 wells in the southern part of the study area where its thickness ranges from 3.5 to 17.1 $\mathrm{m}$ (Kabanov et al. 2016b). Due to its thinness and variable GR signature, the Francis Creek Member has not been credited a separate formal or informal status in previous works.

\section{Prohibition Creek Member}

The Prohibition Creek Member is named after the left-bank outcrop (looking downstream) at Prohibition Creek, UTM 9N 630445E, 7232251N (beds 10 to 18 at the field station 15KOA004; Appendices 1 and 4 in Kabanov et al., 2016a). The member is composed of hard, dark grey to black and variously calcareous to non-calcareous, thinbedded or platy, moderately pyritic mudrocks. It is characterized by low $\mathrm{K}$ and Th values and a total GR within the range or slightly lower than in the overlying Vermillion Creek Member (Figs. 3). The Prohibition Creek Member is notably rich in pyritic-calcareous 
nodules. Thin $(0.1-0.3 \mathrm{~m})$ calcareous beds are rare to common (1-10\% of the member) and composed of tentaculitid argillaceous limestone or, rarely, micritic marly limestone and calcareous mudrock. In cores from Loon Creek O-06 and Little Bear N-09 wells, the Prohibition Creek interval contains some graded calcarenite to calcisiltite laminae with tentaculitids and rare laminae of muddy chertstone. Benthic shelly macrofauna and trace fossils are not recorded except for infrequent pyritized sponge spicules on bedding planes. The proposed Prohibition Creek Member is very similar to the lower part of the Canol Formation in visual character and log signatures (Pugh 1983, 1993; Pyle et al. 2014), but the original subsurface correlation with SP and resistivity logs was very similar to our correlations (figure 10 in Tassonyi 1969). The Prohibition Creek Member is $19-32$ m thick and identified in 16 wells in the same area as the Francis Creek Member (Kabanov et al. 2016b).

\section{Ramparts Formation}

The Ramparts Formation (named after the Ramparts Gorge cliffs; Kindle and Bosworth, 1921) is composed of three main parts referred to as the lower platform (or lower ramp) informal member, Carcajou Member, and Kee Scarp Member (Pyle et al. 2014). This triple subdivision is a simplification and the result of a long and controversial development of the Ramparts nomenclature discussed in many publications (e.g., Pugh 1983, 1993; Muir 1988; Gal et al. 2009; Pyle et al. 2014). The lower platform member refers to an argillaceous and silty fossiliferous bedded limestone overlying and intergrading with the upper Bell Creek Member of the Hare Indian Formation. The upper part of the lower platform limestone grades into the Carcajou bed, which is a thin (1.5-3.0 m) limestone with dark argillaceous and bituminous matrix. The Carcajou bed is traced in 
the subsurface by its elevated GR and often refers to as a Carcajou marker (Fig. 2; Muir 1988). In some sections at Norman Wells, the limestone of the lower platform member is absent or not sufficiently developed, and the Carcajou marker overlies the calcareous and bioturbated siltstone attributed to the upper Bell Creek Member (e.g., Bear Island R34X well; Kabanov 2013). The Kee Scarp Member is defined as a portion of the autochthonous Ramparts Formation above the Carcajou Member. It is composed of cleaner limestones with a coral-stromatoporoid framework recording backstepped development from broader "upper platform member" upward into narrow carbonate banks frequently referred to as the "reef member" (Muir et al. 1984; Muir 1988). A more general term "carbonate banks" (e.g., Yose et al. 2001) is favored, because syngenetic marine cements are very rare, and the actual extent of reef building is not yet clarified. Carbonate-bank interiors show stacking pattern of meter-scale cycles or parasequences (Muir and Dixon 1985; Muir 1988). The isopach map of the Ramparts Formation in the study area, modelled from 21 wells combined with contours of seismic-scale carbonate banks, was published in (Kabanov et al. 2016b).

\section{Canol Formation}

The Canol Formation was defined by Bassett (1961) as a black shale unit directly overlying the Ramparts (Kee Scarp) limestone or, where the latter is absent, directly overlying the Hare Indian Formation. The name of the new unit, meant to replace the informal "bituminous member of the Fort Creek Formation" (Bassett 1961), was taken from Camp Canol located across Mackenzie River from Norman Wells. Its type section 
was chosen along the northwest side of Powell Creek at $65.28^{\circ} \mathrm{N}, 128.77^{\circ} \mathrm{W}$ (Bassett 1961; Pugh 1993; Pyle et al. 2014).

Based on then-available SP and resistivity logs, Tassonyi (1969) divided the Canol Formation into lower, middle, and upper members and demonstrated the likelihood of their traceability in the subsurface, including correlation between the thin Canol sections above Kee Scarp banks (reefs) and thick sections in the off-bank (basinal) areas. Pyle et al. $(2011,2014)$ and Pyle and Gal (2012) divided the formation in outcrops into the basal (or lower) recessive, middle resistant, and upper recessive informal units. Most recently Pyle and Gal (2016) placed the "upper recessive unit" into the base of the Imperial Formation. Our well-outcrop correlation in the SOB area (Fig. 4) indicates that the basal recessive and middle resistant units of Pyle and co-authors, together, match the lower informal member of Tassonyi (1969). Correlation of the middle and upper units of Tassonyi (1969) will be discussed under "Canol-Imperial transitional interval”.

In new cores from the SOB area, the dominant facies of the Canol Formation is black laminated siliceous mudrock enriched in very fine grained $(<50 \mu \mathrm{m})$ pyrite $($ Fig. $8 \mathrm{~A}$ and 8B). The latter is described at the hand lens scale as pyrite dust (evenly dispersed in rock matrix), pyritic streaks (laminar features laterally not exceeding $1 \mathrm{~cm}$; Fig. 8D), and pyritic laminae (laminar features laterally approaching or exceeding core diameter). These types of pyrite are regarded a matrix pyrite, in contrast to nodular pyrite that also occurs in plenty (Fig. 8E). The matrix pyrite is likely composed of framboids diagnostic of anoxic sedimentary environments (Wilkin et al. 1996). Pyritic streaks and laminae in Canol mudrocks tend to be regularly spaced $(1-2 \mathrm{~mm})$ defining characteristic microrhythms (Fig. 8A). Canol mudrocks vary from silty shale to siltstones with deviation into 
pelitomorphic mudrocks and very fine-grained sandstones. Minor facies interlaminated with mudrocks are radiolaritic chertstones (Fig. 8A), carbonates, and red-colored shale seams. The latter are thin $(<2 \mathrm{~cm})$ laminae of alumina-rich shales (Fig. 8A) found at different levels in the HRG. These seams are usually strongly pyritized and contain authigenic anhydrite crystals (Kabanov et al. 2016a). Fine jointing is typical as a result of brittleness related to high $\mathrm{SiO}_{2}$ content; some joint fractures are lined with calcite cement (Fig. 8B). Fine coaly detritus is present throughout the formation, but larger plant impressions are rare (Kabanov et al. 2016a).

\section{Vermillion Creek Member}

The new member replaces the basal recessive informal unit of Pyle et al. $(2011,2014)$ and is identified by dominance of moderately recessive rocks at Prohibition Creek outcrops and GR/SGR signatures in studied sections (Fig. 4). The name refers to the Vermillion Creek outcrop where the basal recessive unit was identified by Pyle and Gal (2013) between UTM 9N 638585E, 7227651N (section base) and UTM 9N 637312E, 7227293N (section top). The Vermillion Creek Member directly overlies the Carcajou marker bed at the Mountain River Tributary section, proposed as a type section for the HRG (Pyle et al. 2014). The member is dominated by typical Canol mudrocks but with fewer calcareous mudrocks and pyritic-calcareous nodules than in the otherwise very similar Prohibition Creek Member. In core the member is variously calcareous and pyritic, and calcareous laminae sometimes contain poorly preserved tentaculitids. Sponge spicules are absent (Kabanov 2015; Kabanov et al. 2016a).

The top of the described unit is picked at a low-gamma calcareous-dolomitic mudrock that forms a traceable resistant rib in outcrops. At Prohibition Creek it is $0.7-3.0 \mathrm{~m}$ thick 
(unit 35 in Appendices 1 and 4 in Kabanov et al. 2016a). This low-gamma marker is emphasized by a sharp reversion to a very high-gamma spike directly above the marker. This gamma marker correlates with low resistivity and SP level traced by Tassonyi (1969) under the name "Canyon Creek marker", which should not be confused with the Canyon Creek sandstone (Canyon Member). The "Canyon Creek marker" of Tassonyi is confidently correlated in the subsurface in the SOB area where the Vermillion Creek Member shows an offshore (westward) thickness increase from 28 to $52 \mathrm{~m}$ based on 16 wells (Kabanov et al. 2016b). A low-gamma horizon that might correspond to the "Canyon Creek marker" is also present in several thick off-bank well sections to the northwest of Norman Wells, allowing for recognition of the two members within the Canol Formation (Appendix 1 in Kabanov et al. 2016b).

\section{Dodo Canyon Member}

The proposed name originates from the Dodo Canyon East outcrop section (UTM 9N 578979E, 7210859N at section top) measured by Pyle and Gal (2012) and Pyle et al. (2014). This unit is wall-forming in outcrops, hence informally named the middle resistant unit by Pyle et al. $(2011,2014)$. It should be noted that based on the GR $\log$ provided by L.J. Pyle and co-authors, the lower one-third of the interval placed by them in the middle resistant unit has to be moved to the Vermillion Creek Member (their basal recessive unit).

The described member is distinctive for the highest pyrite and silica content in the rock matrix and the rarity of calcareous beds. Calcareous seams are scarce and texturally different from the calcareous beds in the Prohibition Creek and Vermillion Creek 
members: they are dominated by authigenic "stellate calcite aggregates" submerged in hard non-calcareous siliceous matrix (Kabanov et al. 2016a). Calcareous allochems (mostly tentaculitids), characteristic of the underlying black shale units, are very rare. Dolomite is also present in the form of pre-compactional authigenic nodules and dolomitic beds (Pyle et al. 2014). The Dodo Canyon mudrocks are notably hard, brittle and rich in chertstone laminae (Fig. 8A). No bioturbation or benthic fossils were encountered. Sponge spicules are nearly absent in both Vermillion Creek and Dodo Canyon members except for rare thin beds where they may be allochthonous. The thickness of the unit ranges from 33 to $47 \mathrm{~m}$ in the SOB area, based on 16 wells (Kabanov et al. 2016b).

The basal few meters of the Canol Formation, as it occurs on top of Ramparts carbonate banks, are intersected by cores in several wells; three of these cores were measured (Norman Wells P32X, Mackenzie River no. 4 (E-27), and Morrow Creek J-71). These cores show cherty pyritic mudrocks with rare intervals of micritic authigenic carbonates. Absence of pyritic-calcareous nodules or tentaculitid laminae matches them with the Dodo Canyon Member, although the on-bank mudrocks are generally more fissile, more radioactive and organic-rich than their counterparts in thick off-bank sections. This visual evidence is not considered conclusive; however, it is consistent with interbedding of the Kee Scarp member and Canol shales (Muir 1988) and indicates that a lower part of the Canol Formation is time equivalent to Kee Scarp carbonate pinnacles. It is assumed that this part mostly corresponds to the Vermillion Creek Member (Fig. 2).

\section{Canol-Imperial transitional interval}


The Canol-Imperial contact is conformable, and its stratigraphy is historically controversial. In the Canol Formation stratotype at Powell Creek, this contact was defined at transition from very fissile hard to soft shale of the upper Canol Formation to 16 m thick "soft back shale" placed by Bassett (1961) in the base of the Imperial Formation. In more recent measurements of the same section, the Canol Formation included the upper fissile dark-colored shales, but excluded the soft recessive mudrock that was very poorly exposed (Gal et al. 2009). In later interpretation of the same section (Pyle et al. 2011, 2014), the hard dark-colored fissile shale has been included in the Canol Formation as "the upper recessive member", and the total Canol thickness was measured in $18.2 \mathrm{~m}$, in difference to $23 \mathrm{~m}$ measured by Bassett (1961). However, L.J. Pyle and coauthors (ibid.) did not specify the existence of a soft mudrock different from the uppermost Canol facies and the overlying Imperial siltstones.

The "upper recessive unit" of the type Canol section has been correlated to a number of thicker Canol sections including Prohibition Creek (Pyle et al. 2011, 2014; Pyle and Gal 2012) where this unit refers to a prominently fissile interval exposed just above the wallforming and siliceous mudrocks of the Dodo Canyon Member (Fig. 4; Kabanov et al. 2016a). However, the very recessive, clay-rich character of this unit makes it poorly exposed and mostly vegetated, obstructing good observation of its upper part and its contact with the overlying unit.

Correlation of the Canol Formation in the subsurface was historically quite different. Based on resistivity logs, Tassonyi (1969) divided the formation into lower, middle, and upper informal units, traceable in then-available wells across the central Mackenzie Plain. Further recognition of Tassonyi's Canol units was hampered by the inability to recognize 
them in other areas and by the uncertainty of their lithologic expression in outcrops, but Pugh (1993) generally followed Tassonyi's choice of the Canol top. Cross-sections on Figures 4 and 5 include the Canyon Creek no. 1, Loon Creek no. 2, and Bluefish no. 1A wells drilled during the Canol Project of 1942-1945. These wells were used by Tassonyi (1969) in his correlation. The Middle Canol unit of Tassonyi (1969) with its distinct low resistivity and dominance of grey shales in cutting samples corresponds to the "Upper Recessive unit" of Pyle et al. $(2011,2014)$. The Upper Canol unit was described by Tassonyi (1969) in Loon Creek no. 2 well as "the interbedding of bituminous and grey shales". Lithology of this "Upper Canol unit" becomes clear only now, with new continuous cores from Canol Shale exploration wells. It is described below under the new name Loon Creek Member.

\section{Mirror Lake Member}

The name originates from the Mirror Lake N-20 exploration well (UTM 9W 603613E, $7210030 \mathrm{~N}$ ) with the type section in the continuous core between 1965.4 and $1942.0 \mathrm{~m}$ (Appendix 7 in Kabanov et al. 2016a). The Mirror Lake Member is a grey shale notably recessive unit with several levels of pyritic tablets (pyritized acritarchs; Fig. 8G) and similarly pyritized sponge spicules. The unit is dominated by silty, subfissile to fissile shales, enriched in expandable clays (Fig. 8C); it also contains minor siltstones and sandstones. Pyritic encrustations on acritarchs and spicules are very fine-grained (Fig. 8G). No bioturbation or benthic fossils were encountered. Sponge spicules are unevenly present: numerous in Mirror Lake N-20 but rare to absent in Loon Creek O-06 and Little Bear N-09 (Kabanov 2015; Kabanov et al. 2016a). Top and base of the unit are gradational. The visual character of the Mirror Lake Member, as it appears in core, is 
very similar to the Francis Creek Member of the Hare Indian Formation. The member is identified in 38 wells across the entire study area where its thickness changes from 5-10 $\mathrm{m}$ on top of Ramparts carbonate banks to $21-59 \mathrm{~m}$ in the SOB area. Thickness of the described member increases eastward in the SOB area indicating development of deltaic lobes (Kabanov et al. 2016b).

\section{Loon Creek Member}

The name originates from the Loon Creek O-06 exploration well (UTM 9W 593319E, $7220841 \mathrm{~N}$ ) with the type section in the continuous core between 1653.25 and $1625.2 \mathrm{~m}$ (Appendix 6 in Kabanov et al. 2016a). The Loon Creek Member is dominated by dark grey subfissile mudrocks rich in silicisponge spicules (Fig. 8F). These mudrocks are somewhat harder than the fissile shales of the Mirror Lake Member but softer than Canol mudrocks; sponge spicules there are mostly not pyritized. The basal $1 / 3$ to $1 / 2$ of the unit is marked by recurrence of black pyritic mudrocks characteristic of the Canol Formation (Fig. 8E). The matrix pyrite in these basal mudrocks is variously developed and locally forms continuous laminae defining micro-rhythms like those observed in the Canol Formation. Upwards, the section shows a gradual return to siliciclastic-rich and pyritelean mudrocks. Thinner Canol-type pyritic mudrocks are locally present in the upper portion of the unit, (e.g., 404.9-406.3 m in Canyon Creek no. 1 well; Fig. 9). Sedimentary carbonates in the Loon Creek Member are very rare, occurring as admixture of poorly preserved tentaculitids.

Unlike the underlying shale units, the thickness of the Loon Creek Member is uneven and shows significant NW-SE facies changes at the distance of tens of kilometers. The upper 
part of the Loon Creek Member is dominated by dark colored shales in the Loon Creek O-06 and Mirror Lake N-20 wells, but, further southeast, it shows thick-bedded alternation of dark and light grey shales as perceived from cuttings (Bluefish K-73), and in East MacKay I-78 it grades into a thick shale-siltstone alternation attributed to the Canyon Member (Fig. 3). The member is identified in the same wells as the Mirror Lake Member. In the SOB area, the thickness of the Loon Creek member changes from 28 to $95 \mathrm{~m}$, with two values likely as small as 6 to $12 \mathrm{~m}$ in Canyon Creek \# 1 and Loon Creek G-78 wells. At Norman Wells and further northwestward, the unit is 10-26 m thick. The facies and thickness heterogeneity of the Loon Creek Member is thought to indicate a transition from fondothemic strata of Canol Formation to westward-accreting clinoforms characteristic of the Imperial Formation (Hadlari et al., 2009).

\section{Authigenic carbonates}

The authigenic (early diagenetic) development of carbonates in black redox to anoxic sediments is widely known (e.g., Lash and Blood 2004). Pugh (1993) was the first who indicated "thin carbonate developments at the top of the Canol Formation in a $100 \mathrm{~km}$ area around Norman Wells", referring to 6-12 m thick intervals in several wells where shales are interbedded or replaced by limestone or dolostone. After updating the formation tops, these intervals are matched to the Mirror Lake and Loon Creek members (Fig. 2; Kabanov et al. 2016b). Thick carbonates are the spatially restricted authigenic features, including concretionary forms. Smaller $(0.5-3 \mathrm{~cm})$ pre-compactional nodules of micritic calcite and dolomite are encountered in the Loon Creek Member (Kabanov et al. 2016a). A thick argillaceous micritic limestone was cored at $626.7-629.7 \mathrm{~m}$ of Bluefish no. 1 (A-37) well (Fig. 5). This limestone was previously miscorrelated with the 
Ramparts Formation (Tassonyi 1969; Hogue and Gal 2008). Reexamination of this core revealed lack of bioturbation and benthic fossils and an early diagenetic (precompactional) character of carbonate impregnation in a laminated facies. The resistivity $\log$ at the carbonate-impregnated interval $(605-629 \mathrm{~m})$ is inverted towards dielectric values; its correlation to the Mirror Lake Member and perhaps partly to the uppermost Dodo Canyon member is supported by log signatures in the underlying part of the section.

\section{Canyon Member}

The name originates from the Canyon Creek no. 1(G-51) well at UTM 9W 621035E, 7230207N where it was first called the Canyon Creek member by Stewart (1945). The typical (Type-A) Canyon Member is a thin (25-31 m) and discontinuous sandstonedominated unit; in some sections it is dominated by siltstones with minor or no sandstones (Tassonyi 1969; Pugh 1983). The Canyon Member is also referred to as "the basal Imperial sandstone" (Hadlari et al. 2009). The unit is relatively resistant, underlain and overlain by more recessive shales, and has been used as a mapping marker for the Canol/Imperial contact (Aitken et al. 1982). Because of the laterally discontinuous nature of this unit, Pugh (1983) has called it "the Canyon Creek sandstone lentil". The unit was included in the table of formations as the Canyon Member (Hogue and Gal. 2008) and recognized by MGM Energy explorationists during the drilling campaign of 2012-2013 as interval 1676-1735 m MD in East Mackay I-78 well (Fig. 3).

Reviews of cores from the Canyon Creek no.1, no.2, and Loon Creek no.2 wells show that the Canyon Member in type localities (Canyon Type A) is composed of very fine- 
grained quartzose sandstones with minor siltstones and shales; the stratal pattern is organized in thick sandstone-dominated Bouma rhythms (Fig. 9) and represents the coarsening-upward succession of a prograding turbidite fan (Hadlari et al. 2009). The base of the Canyon (A) member is chosen at the transition to the mudrock-dominated interval where sandstone beds still play significant role (Fig. 9). The key to the correlation is found in mudrock interbeds preserved as loose chips in core boxes. In the type section, the interval assigned to the Canyon (A) Member contains brownish greygrey, subfissile to fissile, non-pyritic, spiculiferous shales with occasional pyritic tablets (acritarchs) and no benthic fossils, except for spicules. This shale most resembles the upper Loon Creek facies in the Loon Creek O-06 and Mirror Lake N-20 wells. An interval 404.9-406.0 m of Canyon Creek no.1 well is composed of black pyritic mudrock. Downwards, the latter grades into fissile non-pyritic shale. The described mudrock succession favors correlation of the Canyon (A) unit, or a big part of this unit, with the upper portion of the Loon Creek Member. The basal Imperial shale in the core from Mirror Lake N-20 well is softer and lighter colored, non-spiculiferous, and contains small-fossil assemblage of bivalves, cephalopod shells and beaks, tentaculitids, and pelagic ostracods described by S. Gouwy in Kabanov et al. (2016a).

Offshore (southwestward) from the Loon Creek no. 2 well, the sandstone disappears, and this stratigraphic level is only marked by an interval with important siltstones and rare thin sandstone laminae that can be picked in most wells by its prominent low-gamma marker (Fig. 4). We propose to call such thin intervals "the Canyon Member type B" (Figs 3-5). The full Canyon (B) section is cored in Mirror Lake N-20 (1904.9-1910.40 m MD) where the log marker is identified at 1907.1-1907.87 $\mathrm{m}$. This thin bed is composed 
of hard grey weakly calcareous mudrocks and siltstones with heterolithic lamination and traces of thin starved ripples or channel cuts. Despite standing out on logs, this interval does not show significant visual difference from the underlying and overlying parts of the Canyon (B) unit. The Canyon (B) log marker disappears southeastward at the East MacKay I-78 well where a thick (1680-1731 m) interval of siltstone-shale alternation is placed in the Canyon Member. A similar shale-siltstone interval assigned to the Canyon Member (Hogue and Gal, 2008) is developed in wells Deh Cho-1(B-25) and Deh Cho2(B-14), about $10 \mathrm{~km}$ to the SE of the Norman Wells Oilfield.

\section{WELL LOG SIGNATURES}

A quick analysis of selected LAS files using median and standard square deviation gives quantitative $\log$ signatures of lithostratigraphic members (Tables 1 and 2). Given the variability of tools and calibrations, log data are organized into two groups with new wells drilled in the SOB area (Table 1) and the wells drilled in 1980s through early 2000s in the northwestern part of the study area including Norman Wells Oilfield (Table 2).

The "Basal Imperial" stands for the lower $30 \mathrm{~m}$ of the lower Imperial shale just above the Canyon or Loon Creek members. The Basal Imperial shale shows remarkably flat GR and SGR values at 73-127 gAPI in different wells and relatively high CGR of 67-99 gAPI in the southern part of the study area (Figs. 3-6). Extremely low departures from median are expressed in negligible standard deviations (Tables 1 and 2). The Canyon Member is laterally variable in log signatures reflecting its lithology. South of Norman Wells, the sections of the Type A Canyon Member show an acoustic slowdown and a moderate increase in resistivity comparing to shales above and below, and a low-gamma and high resistivity marker flags the Canyon (B) unit (Figs 3 and 4). At the Norman 
Wells Oilfield, the Canyon (B) unit is tentatively assigned to a thin (5-10 m) interval with one or more weak low-gamma kicks (e.g., Mackenzie River no. 4 on Fig. 3). The Canyon Member is not recognized in most wells north and northwest of Norman Wells except for Discovery Ridge H-55 where a thick interval with GR offset towards low values and several high-resistivity spikes is assigned to the Type-A Canyon Member (Fig. 6).

The Loon Creek Member shows a gradual downward increase in total GR and an overall inverse development of CGR in line with its changing lithology (Fig. 6). The basal onethird of this unit is distinctly radioactive with uranium-dominated SGR, which keeps the median GR value of the whole unit higher than in the units above and below (Table 1). The underlying Mirror Lake Member is distinct by a drop of GR and greater contribution of CGR (Figs. 3-6). This gamma-ray pattern is distinct in wells south of and across the Norman Wells Oilfield, but weakens in the northwestern part of the study area where some wells do not show its GR signature at all (e.g., Morrow Creek J-71; Fig. 6). The Mirror Lake Member is prominently conductive with two to three times drop in median resistivity values comparing to the basal Loon Creek Member and three to seven times drop comparing to the underlying Canol Formation. This resistivity signature also retains in sections where the member is not expressed on GR (e.g., Morrow Creek J-71). Inversion towards dielectric values occurs rarely and only in sections where the Mirror Lake Member is impregnated with carbonates (Bluefish no. 1 well on Fig. 5). Another clue for the correlation of this member is provided by the offset of compressional sonic towards slowest values for the HRG exceeding $300 \mu \mathrm{S} / \mathrm{m}$ in most sections (Tables 1 and 2), which renders its potential for seismic stratigraphic resolution. 
The Canol Formation stands out by its highest GR in the studied succession with median values ranging between 150 and 180 gAPI in thick off-bank sections (Table 1) and variable median values frequently exceeding 200-250 gAPI in thin Canol sections on top of Ramparts carbonate banks (Table 2). The Dodo Canyon Member shows the lowest CGR values in the succession (median 35-48 gAPI), and the Vermillion Creek Member is slightly richer in thorium and potassium with CGR median ranging between 47 and 61 gAPI (Table 1). High silica content makes Canol mudrocks least conductive among the studied shale units. Significant dispersal of resistivity values within the Canol Formation expressed in high standard deviations (Tables 1 and 2) indicates thin interbedding of more conductive clay-rich and less conductive silica-rich beds, and this contrasting bedding pattern is especially distinct in the Vermillion Creek Member (Figs. 5 and 6).

Well log signatures of the Ramparts Formation have been repeatedly discussed by previous workers (Tassonyi 1969; Muir 1988; Pugh 1983; Gal et al. 2009; Pyle et al. 2014). We do not address this part of the HRG any further except for noting that resistivity logs of three parts of the Ramparts Formation in Table 2 are variously influenced by conductivity of pore fluids or gas and therefore are not considered as having sufficient stratigraphic utility.

The Bell Creek Member is characterized by relatively flat log signatures with GR median values ranging between 75 and 130 gAPI and LLD/ILD median values within the range of 10-38 Ohm*m (Table 2). The Prohibition Creek Member is distinct by having higher and more serrated GR (median 128-148 gAPI) and higher resistivity. CGR values in this black shale equivalent of the Bell Creek Member stay low and close to the median values of the Vermillion Creek Member (Table 1). Gradations to black shale known in some 
interbank sections of the upper Hare Indian Formation to the northwest of Norman Wells are expressed in higher resistivity, although total gamma can remain at the background level of the Bell Creek Member (e.g., Hoosier F-27 well on Figs. 3 and 6).

The Francis Creek Member expresses in doubling CGR values compared to the black shale units above and below and by its prominent spike in conductivity with only 6 to 15 Ohm*m median values of M2RX and M2R9 logs (Table 1). The total GR in the Francis Creek Member is only slightly lower or stays within the GR range of the Prohibition Creek Member (Fig. 3 and Table 1). The Bluefish-Francis Creek interval is also characterized by compressional DT slowdown to $272-296 \mu \mathrm{S} / \mathrm{m}$ median values against 254-264 $\mu \mathrm{S} / \mathrm{m}$ at the Prohibition Creek - Dodo Canyon interval (Table 1). The Bluefish Member is characterized by a sharply serrated pattern in GR/SGR and particularly by resistivity $\operatorname{logs}$ reflecting unevenness of limestone-shale alternation and pelagic vs. siliciclastic contribution into rock matrix (Tables 1 and 2). This interval is overall enriched in both $\mathrm{U}$ and K-Th lines. However, CGR and SGR do not covary within the Bluefish Member (Pearson $r$ values 0.1 to 0.2 ).

\section{CHEMOSTRATIGRAPHY}

Lithogeochemical data from Little Bear N-09 and Loon Creek O-06 wells provide highresolution logs for 58 elements but describe a narrow area boxed in between $65^{\circ} 10^{\prime} \mathrm{N}$, $127^{\circ} 20^{\prime} \mathrm{W}$, and $64^{\circ} 50^{\prime} \mathrm{N}, 126^{\circ} 20^{\prime} \mathrm{W}$ (Fig. 1). Broader-area characterization is a task for the near future requiring adjustment in stratigraphic correlation with the NTGS 
Mackenzie Project database (Gal and Pyle 2012; Pyle and Gal 2012, 2013, 2016; Pyle et al. 2011, 2014).

\section{Main oxides}

In Little Bear N-09 and Loon Creek O-06, variations and median values of major elements divide the succession into three main packages: the alumina-rich (clay-rich) Bluefish-Francis Creek interval with 10-18\% median $\mathrm{Al}_{2} \mathrm{O}_{3}$ and 57-60\% median $\mathrm{SiO}_{2}$, the clay-lean siliceous Prohibition Creek - Dodo Canyon interval with 5.8-9\% median $\mathrm{Al}_{2} \mathrm{O}_{3}$ and 68-78.5\% median $\mathrm{SiO}_{2}$, and the generally clay-rich mudrocks above with 1317\% median $\mathrm{Al}_{2} \mathrm{O}_{3}$ and $60-66 \%$ median $\mathrm{SiO}_{2}$. Inside the overall clay-rich interval, the black shale of the lower Loon Creek Member is a prominent clay-lean and siliceous bed (12.5\% median $\mathrm{Al}_{2} \mathrm{O}_{3}$ and 67-69\% median $\mathrm{SiO}_{2}$ ). The Dodo Canyon Member stands out by its extremely high matrix siliceousness $\left(75-79 \%\right.$ median $\left.\mathrm{SiO}_{2}\right)$ and lowest $\mathrm{Al}_{2} \mathrm{O}_{3}$ for the whole succession (5.7-6.7\%). Carbonate components in the rock matrix change most significantly across Vermillion Creek / Dodo Canyon contact. Below this contact, $\mathrm{CaO}$ occurs at the background of $1.7 \%$ median values (except for the thin non-calcareous Francis Creek Member) and is bound in both calcite and dolomite; above this contact, median values of $\mathrm{CaO}$ are well below $1 \%$, and in spikes itmostly resides in dolomite as indicated by nearly stoichiometric match of $\mathrm{CaO}$ and $\mathrm{MgO}$ (Fig. 11). A prominent normally graded $8-10 \mathrm{~m}$ thick calcareous horizon is traced in the Vermillion Creek Member; its base is found at $1781.5 \mathrm{~m}$ in Little Bear N-09 and at $1761.8 \mathrm{~m}$ in Loon Creek O-06 (Figs. 10 and 11). An offshore (westward) trend between Little Bear N-09 and Loon Creek O-06 is expressed in consistent decrease of siliciclastics-bound elements $\left(\mathrm{Al}_{2} \mathrm{O}_{3}\right.$, 
$\mathrm{TiO}_{2}, \mathrm{~K}_{2} \mathrm{O}$ ) in each lithostratigraphic member. Silica shows offshore increase in each member indicating its predominantly pelagic (radiolarian) source.

\section{Molybdenum}

Many trace metals (TM) tend to accumulate in a range of redox to anoxic sediments and are used as indicators of black shale depositional environments (Tribovillard et al. 2006; Algeo and Rowe 2012). Popular notation of TM enrichment is the enrichment factor (EF) defined as $\mathrm{EF}($ element $\mathrm{X})=\left(\mathrm{X} / \mathrm{Al}_{\text {sample }}\right) /\left(\mathrm{X} / \mathrm{Al}_{\text {average shale }}\right)$ (Tribovillard et al. 2006). If EFX is greater than 1 , then element $X$ shows enrichment, and if it is less than 1 , then it is considered depleted. Concentration of elements in an average shale of Wedepohl (1971, 1991) are frequently chosen as standard or "Clarke values" (Tribovillard et al. 2006), including the lithogeochemical proxies in studied rocks (Pyle et al. 2014; Kabanov et al. 2015).

In a range of analyzed TMs, molybdenum shows the most pronounced stratigraphic pattern and the strongest enrichment against $1.3 \mathrm{ppm}$ in the average shale of Wedepohl (1991). Black shale units are enriched in Mo compared to grey shale units (Fig. 10): median EFMo in the Prohibition - Dodo Canyon interval is 82-108 against 25-29 in the Francis Creek and 9-15 in the Mirror Lake members. The Bluefish Member shows intermediate EFMo values of 81-91. The black shale of the lower Loon Creek Member shows moderate EFMo with 18 median value, which is less than in the grey shale of the Francis Creek Member. Distribution of Mo in black shale stratal packages is very uneven. The Dodo Canyon stands out by its box-like EFMo signature with 112-113 median values, indicating strongest anoxia probably caused by deepest and protracted drowning. 
A thinner $(5-10 \mathrm{~m})$ high-Mo horizon is detected in the lower one-third of the Vermillion Creek Member (Fig. 10).

\section{Phosphorus}

Phosphorus is assessed by its enrichment factor (EFP), which is the ratio of $\mathrm{P}_{2} \mathrm{O}_{5}$ in a sample to the shale average of Wedepohl (1991) used as a Clarke value. The studied mudrock succession is depleted in $\mathrm{P}_{2} \mathrm{O}_{5}$ throughout with EFP median values 0.5 to 0.8 and only rare spikes above 1 (1.6 maximum). This, along with the lack of phosphorite nodules, rarity of fish debris, and likely modest conodont abundance attests for nutrientstarved character of the HRG depositional environment in the study area.

\section{Organic matter properties based on pyrolysis}

The organic matter in Loon Creek O-06 and Little Bear N-09 wells is of high quality with very high S2 vs. TOC, which is characteristic of Canol play kerogens and offsets them towards Type I (Pyle et al. 2014, 2015; Kabanov et al. 2015). Kerogens of the Bluefish Dodo Canyon interval generally belong to type I-II with very low oxygen index (Fig. 10). TOC values at this interval have 4.5 wt. $\%$ median and $9.1 \mathrm{wt} \%$ maximum values. The Francis Creek grey shale member shows depressed TOC with $2.6 \%$ median and 4.9 wt. \% maximum values, and thick Bell Creek grey shales reportedly contain even less kerogen with median and average TOC values within 0.3-2.0\% (Pyle et al. 2014). Nine samples from the condensed Dodo Canyon section of Norman Wells P-32X well are even richer in kerogen with 7.1 wt. \% median and 16.9 wt. \% maximum TOC (Kabanov 2015). 
The Mirror Lake and Loon Creek members of Loon Creek O-06 and Little Bear N-09 wells are distinct from the underlying part of the HRG by low TOC $(2.1 \%$ median and 3.8\% max), lowered Tmax, and the elevated hydrogen index (Fig. 10; Kabanov et al. 2015, 2016a). The Mirror Lake Member is very distinct by the spike of oxygen index offsetting its kerogen towards Type III (Fig. 10), which is most likely caused by the influx of coaly detritus. Thermal maturity parameters are outside this study and discussed elsewhere (Issler et al. 2005; Pyle et al. 2014, 2015; Kabanov et al. 2016a).

\section{MINERALOGY OF SHALE UNITS}

Pyle et al. (2014) surveyed mineral composition of Horn River mudrocks based on semiquantitative XRD data from 187 well samples and several dozen outcrop samples. The Canol Formation was shown to have the highest mean quartz content of $77 \%$ in 78 samples. The lower Imperial and Bluefish members give mean quartz values within 64$65.5 \%$. The Bell Creek member is reported to have $62.5 \%$ mean quartz and the highest content of micas, clay and chlorite, but this value combines black shales of the Prohibition Creek Member (Bear Rock O-20, Bluefish K-71, and Blueberry Creek K-53) and the grey-shale facies that are likely developed further south of the study area (wells Dahadinni B-20 and Silvan Plateau G-51; Pyle et al. 2014).

Our new data include 67 samples from Little Bear N-09 well collected from the upper Hume Formation to the Mirror Lake Member (Fig. 11; Kabanov et al., 2016). Unfortunately, no new data on Loon Creek Member are available yet. The XRD shows illite composition of clays and their overall minor participation in the rock matrix of Hare 
Indian and Canol formations. Kaolinite and mixed-layer clays are present as nonquantifiable traces. The clay content is higher in the Bluefish - Francis Creek interval (22.0\% median) and Mirror Lake Member (27-53\% in three samples) than at the Prohibition Creek - Dodo Canyon black shale interval. The latter shows only 15\% median values of illite, and the Dodo Canyon only $9.5 \%$ median illite.

Carbonates are represented by a mixture of calcite and dolomite at the Bluefish Vermillion Creek interval and dolomite in the Dodo Canyon member (Fig. 11). Three samples showed presence of barytocalcite. The Mirror Lake Member stands out by predominantly siderite composition of the carbonate component (Fig. 11).

\section{CONODONT BIOSTRATIGRAPHY}

Figure 12 gives an overview of the current state of the conodont research in the area. The localities used to construct the range chart are Powell Creek (Uyeno 1978, 1986), Rumbly Creek (Uyeno 2008), Dodo Canyon (Gouwy 2016a), the Norman Wells quarry, Prohibition Creek (Gouwy 2016b) and cores from the Mackenzie River No. 4 and Loon Creek O-06 wells. Several conodont zones can be recognised so far, but the conodont zonal bases cannot be accurately positioned because of the sample scarcity. This might also be the reason why the hemiansatus and semialternans/latifossatus zones have not been identified so far.

The contact between the Hume and Hare Indian formations is situated within the ensensis Zone (upper Eifelian) based on the identification of Polygnathus linguiformis subsp. A sensu Uyeno \& Bultynck 1993 (Walliser \& Bultynck 2011) in the uppermost part of the 
Hume Formation (Gouwy, unpublished data Rumbly Creek), and P. ensensis (T. Uyeno, personal communication) near the base of the Bluefish Member (lowermost part of the Hare Indian Formation). Polygnathus hemiansatus (index taxon for the base of the Givetian) has not yet been found in the area; the base of the Givetian is therefore tentatively placed in the lowermost part of the Bluefish Member. The contact between the latter and the Bell Creek Member is positioned within the timorensis Zone (lower Givetian) relying on a fauna association including $P$. amphora somewhat above the contact in Dodo Canyon (sample re-assessed by Gouwy, 2016a). The base of the Ramparts Formation is situated within the upper part of the ansatus Zone. Fauna typical for the semialternans/latifossatus Zone is not yet discovered. Schmidtognathus peracutus and Klapperina disparilis indicating the bases of the hermanni and disparilis zones respectively have both been identified within the lower part of the Ramparts Formation (Powell Creek, Uyeno 1978). The norrisi Zone was identified in the uppermost part of the Ramparts Formation in the same outcrop. An isolated sample taken from the basal part of the Canol Formation at Rumbly Creek contains a juvenile specimen of Ancyrodella binodosa (Uyeno 2008), indicating this level should already be placed in the Frasnian. The index taxon for the transitans Zone (Palmatolepis transitans) was identified in the uppermost limestone layer of the Kee Scarp Member in the Kee Scarp Quarry at Norman Wells and in a nodule level at $4.5 \mathrm{~m}$ above the base of the Canol Formation in Powell Creek (Uyeno 1978). The base of the punctata Zone was recognized in the lowermost part of the Dodo Canyon Member in Prohibition Creek indicated by the first occurrence of $P$. aequalis and in the first deposits of the Canol Formation on top of 
the Kee Scarp Member in the Kee Scarp Quarry at Norman Wells based on the first occurrence of Pa. punctata.

The available conodont data do not indicate any significant stratigraphic gaps across the Hume/Bluefish and the Ramparts/Canol contacts. So far, no conodont data are available between the basal part of the Dodo Canyon Member and the poorly constrained middle part of the Imperial Formation (Fig. 2).

\section{CONCLUSIONS}

This study upgrades lithostratigraphy of the HRG of central Mackenzie Valley with new Francis Creek and Prohibition Creek members within the upper part of the Hare Indian formation. We also propose a two-member division of the Canol Formation and define the Mirror Lake and Loon Creek members in the lower part of the Imperial Formation. All these members are confidently traced in the SOB area. In the vicinity of Norman Wells, the Francis Creek and Prohibition Creek members thicken and grade into the grey shale deposits of the Bell Creek Member in its herein proposed definition. Correlation and isopach maps of described units are based on 41 wells drilled within NTS map areas 96C-E.

The black calcareous mudrocks of the Bluefish Member in the base of the HRG onlap the benthic Hume limestone with a 0.3-2.0 m thick condensed section and local hardgrounds. This contact is identified as a "drowning unconformity". The Bluefish Member is overlain by the Francis Creek member, a thin $(3.5-17.1 \mathrm{~m})$ clay-rich grey shale with pyritized acritarchs and sponge spicules. 
The overlying black shale succession in the SOB area is composed of three members. The 16-32 m thick Prohibition Creek Member now replaces the informal black shale member of the Hare Indian Formation. The overlying Canol Formation, 61-105 m thick, is divided into the Vermillion Creek and Dodo Canyon members. The whole black shale succession is radioactive, siliceous (68-78.5\% median $\left.\mathrm{SiO}_{2}\right)$, pyritic, and generally claylean $\left(5.8-9 \%\right.$ median $\left.\mathrm{Al}_{2} \mathrm{O}_{3}\right)$, with $4.5 \%$ median TOC and type I-II kerogens. The Prohibition Creek and Vermillion Creek members are variously calcareous. The Dodo Canyon member is non-calcareous but partly dolomitic, and $\mathrm{SiO}_{2}$ content reaches highest median values of $75-79 \%$, which is expressed in brittleness and resistant wall-forming behavior in outcrops. The Dodo Canyon Member records the strongest and most protracted anoxia as indicated by the highest molybdenum concentrations.

Sharp thickness fluctuations and insufficient data do not permit recognition of members inside Canol Formation to the N-NW of Norman Wells. The Vermillion Creek Member probably deposited coevally with the late backstepping phase of Ramparts carbonates known as the Kee Scarp Member. The thin (2-15 m) Canol Formation, as it occurs on top of the Kee Scarp carbonate banks, is correlated to the Dodo Canyon Member of the SOB area. The Canol Formation grades upward into the Mirror Lake Member placed within the base of the Imperial Formation, but historically described as the "middle Canol informal member". This member is a distinct grey-shale unit with kerogens offset towards type III due to abundance of coaly detritus. Admixture of siderite and ten-fold drop in Mo concentration, as compared to the Canol Formation, indicate a transition from anoxic to suboxic (redox) depositional environments. The Loon Creek Member above is marked by recurrence of Canol-type black shales in its lower one-third and gradual 
recovery of grey shale facies in the upper part of the unit. The facies and thickness of the Mirror Lake - Loon Creek succession are laterally uneven, recording transition from fondothemic strata of the Canol Formation to westward-accreting clinoforms of the Imperial Formation.

The upper part of the Loon Creek member is overlain and laterally grades into coarsergrained facies of the Canyon Member. Definition of the latter is extended by including a thin (3.5-9.0 m) siltstone-enriched mudrock unit developed westward (offshore) from typical siltstone and sandstone dominated Canyon Member. This offshore unit, called Canyon (B) Member, is traced in most wells by its distinct low-gamma marker.

A rather solid conodont biostratigraphic framework of the HRG has been built over the past decades. All standard conodont zones from the uppermost Eifelian (ensensis Zone) up to the middle Frasnian (punctata Zone) are recognized except for the hemiansatus and semialternans/latifossatus zones, what could be due to lack of conodont samples or large sampling intervals in those specific parts of the section. The available data do not suggest significant stratigraphic gaps in the HRG. Further research will constrain the positions of the zonal bases, will establish the presence or absence of the two non-identified zones and will provide valuable stratigraphic information on the upper part of the Canol Formation and the entire Imperial Formation.

\section{ACKNOWLEDGEMENTS}

This work is a contribution to the Mackenzie Project of the Geomapping for Energy and Minerals Program (GEM-2). The authors are indebted to critical reviewers Brian R. Pratt and Gordon C. Baird, and the internal GSC reviewer Keith Dewing. Thanks are due to colleagues Karen M. Fallas (who also led field party), Tom Uyeno, Thomas Hadlari, Ping 
Tzeng, Kezhen Hu, Chunqing (Dennis) Jiang, Tom Brent, Andrew Mort, Bernard MacLean, Robert MacNaughton, Christine Deblonde (all at GSC), and Llew Williams (Paramount Resources). Damien J. Weleschuk, Sarah Saad, Leanne Tingley, Stefan De Freitas, and Wing C. Chan are thanked for field and lab assistance. Cores have been sampled for analyses under NEB sampling permissions \#\# 12599, 12616, and 12619 issued in 2013- 2015. This is a GSC (ESS, Natural Resources Canada) contribution no. 20160092.

\section{REFERENCES}

Aboriginal Affairs and Northern Development Canada (AANDC) 2014. Northern oil and gas annual report for 2013, 30 p., http://www.aadncaandc.gc.ca/eng/1398800136775/ 1398800252896\#chp3 [cited 27 May 2016].

Aboriginal Affairs and Northern Development Canada (AANDC), 2015. Northern oil and gas annual report for 2014, 25 p., http://www.aadncaandc.gc.ca/eng/1398800136775/ 1398800252896\#chp3 [cited 27 May 2016].

Aitken, J.D., Cook, D.G., and Yorath, C.J. 1982. Upper Ramparts River (106G) and Sans Sault Rapids (106H) map areas, District of Mackenzie. Geological Survey of Canada, Memoir 388.

Algeo, T.J., and Rowe, H. 2012. Paleoceanographic applications of trace-metal concentration data. Chemical Geology, 324-325: 6-18.

Bassett, H.G. 1961. Devonian stratigraphy, central Mackenzie River region, Northwest Territories, Canada. Geology of the Arctic, 1: 481-495. 
Bassett, H.G., and Stout, J.G. 1967. Devonian of Western Canada. In International Symposium on the Devonian System, Calgary, 1967. Alberta Society of Petroleum Geologists, 1: 717-752.

Behar, F., Beaumont, V., and Penteado, H.L. de B. 2001. Rock-Eval 6 Technology: Performances and Developments. Oil and Gas Science and Technology -Rev. IFP, v. 56(2): 111-134.

Catuneanu, O. 2006. Principles of sequence stratigraphy. Elsevier, Amsterdam, Boston, Heidelberg.

Cohen, K.M., Finney, S.C., Gibbard, P.L. and Fan, J.-X. 2013. The ICS International Chronostratigraphic Chart. Episodes, 36: 199-204.

Ellis, D.V., and Singer, J.M. 2008. Well logging for earth scientists. $2^{\text {nd }}$ ed., Springer Netherlands.

Gal, L.P., Pyle, L.J., Hadlari, T., and Allen, T.L. 2009. Chapter 6 - Lower to Upper Devonian strata, Arnica - Landry Play, and Kee Scarp Play. In Regional geoscience studies and petroleum potential, Peel Plateau and Plain, Northwest Territories and Yukon. Project Volume. Edited by L.J. Pyle and A.L. Jones. NWT Open File Report 2009-02 and YGS Open File 2009-25, pp. 187-289.

Gal, L.P., and Pyle, L.J. 2012. Petroleum potential data (conventional and unconventional) for Horn River Group from 26 exploration wells - NTS 95N, 96C, 96D, 96E, and 106H, Northwest Territories, Northwest Territories Geoscience Office; NWT Open File Report 2012-009. 
Godet, A. 2013. Drowning unconformities: Palaeoenvironmental significance and involvement of global processes. Sedimentary Geology, 293: 45-66.

Gouwy, S. 2016a. Reassessment of one Devonian conodont sample from the Canol Formation, Dodo Canyon, NWT collected by Adrienne Jones (NTGO) and submitted under R.B. MacNaughtons's MacKenzie Delta and Corridor: Mapping for energy (MATADOR) project in 2011 NTS 096E/03. CON. NO. 1767-6; Geological Survey of Canada, Paleontological Report 1-SAG-2016.

Gouwy, S. 2016b. Report on 15 conodont samples from the Horn River Group (Hare Indian and Canol formations), Prohibition Creek, NWT, NTS 96E/01 collected and submitted by Pavel Kabanov (GEM Shield to Selwyn Basin) Con. No. 1808; Geological Survey of Canada, Paleontological Report 3-SAG-2016.

Hadlari, T., 2015. Oil migration driven by exhumation of the Canol Formation oil shale: A new conceptual model for the Norman Wells oil field, northwestern Canada. Marine and Petroleum Geology, 65: 172-177.

Hadlari, T., Tylosky, S.A., Lemieux, Y., Zantvoort, W.G., and Catuneanu, O. 2009. Slope and submarine fan turbidite facies of the Upper Devonian Imperial Formation, northern Mackenzie Mountains, NWT. Bulletin of Canadian Petroleum Geology, 57: $192-208$.

Hamblin, A.P. 2006. The "Shale Gas" concept in Canada: A preliminary inventory of possibilities; Geological Survey of Canada, Open File Report 5384. doi:10.4095/222641. 
Hannigan, P.K., Morrow, D.W., and MacLean, B.C. 2011. Petroleum resource potential of the northern mainland of Canada (Mackenzie Corridor); Geological Survey of Canada, Open File Report 6757, 271 p. doi:10.4095/289095.

Hayes, B.J.R. 2011. Regional characterization of shale gas and shale oil potential, Northwest Territories; NWT Open File Report 2011-08.

Hogue, B.C., and Gal, L.P. 2008. NWT Formation Tops for Petroleum Exploration and Production Wells: 60 to $80^{\circ} \mathrm{N}$; Northwest Territories Geoscience Office, NWT Open Report 2008-002.

House, M.R. 2002. Strength, timing, setting and cause of mid-palaeozoic extinctions. Palaeogeography, Palaeoclimatology, Palaeoecology, 181: 5-25.

Hume, G.S., and Link, T.A. 1945: Geological investigations in the Mackenzie River area, Northwest Territories; Geological Survey of Canada, Paper 45-16.

Issler, D.R., Grist, A.M., Stasiuk, L.D., 2005. Post-Early Devonian thermal constraints on hydrocarbon source rock maturation in the Keele Tectonic Zone, Tulita area, NWT, Canada, from multi-kinetic apatite fission track thermochronology, vitrinite reflectance and shale compaction. Bull. Can. Pet. Geol. 53, 405-431.

Kabanov, P.B. 2013. Revisiting legacy core and cross sections from the sub-Imperial Devonian of Mackenzie River Corridor with emphasis on formation boundaries. Part 1. Wells Kugaluk N-02, Norman Wells P32X, Imperial Bear Island R34X, Maida Creek F57, and Devo Creek P45; Geological Survey of Canada, Open File 7466. doi:10.4095/292866. 
Kabanov, P. 2015. Geological and geochemical data from Mackenzie Region. Part I. Devonian cored sections and new geochemical, $\delta^{13} \mathrm{C}-\delta^{18} \mathrm{C}$, and pyrolysis data; Geological Survey of Canada Open File Report 7840.

Kabanov, P., Saad, S. Weleschuk, D.J., and Sanei, H. 2015. Geological and geochemical data from Mackenzie Region. Part II: Lithogeochemistry and Rock-Eval data for the Devonian black shale cored interval of Little Bear N-09 well (Mackenzie Plain, Horn River Group); Geological Survey of Canada, Open File 7948.

Kabanov, P., Gouwy, S., Lawrence, P.W., Weleschuk, D.J., and Chan, W.C. 2016a. Geological and geochemical data from Mackenzie Corridor. Part III: New data on lithofacies, micropaleontology, lithogeochemistry, and Rock-Eval pyrolysis, Devonian Horn River Group of Mackenzie Plain and Norman Range, Geological Survey of Canada, Open File 7951.

Kabanov, P., Fallas, K.M., and Deblonde, C. 2016b, Geological and geochemical data from Mackenzie Corridor. Part IV: Formation tops and isopach maps of Horn River Group and basal beds of Imperial Formation, central Mackenzie Plain, NTS map sheets 96C-E. Geological Survey of Canada, Open File 8023.

Kabanov, P., Percival, J. B., Bilot, I., and Jiang, C.(D.) 2016. Geological and geochemical data from Mackenzie Corridor. Part V: New XRD data from Devonian cores and mineralogical characterization of mudrock units. Geological Survey of Canada, Open File 8168.

Kindle, E.M., and Bosworth, T.O. 1921. Oil-bearing rocks of lower Mackenzie River valley; Geological Survey of Canada, Summary Report 1920, Part B: 37-63. 
Lash, G.G., and Blood, D. 2004. Geochemical and textural evidence for early (shallow) diagenetic growth of stratigraphically confined carbonate concretions, Upper Devonian Rhinestreet black shale, western New York. Chemical Geology, 206: 407-424.

Lawton, D.C., and Isaac, J.H. 2005. Geophysical evidence for thin-skinned structural deformation in the Norman Range, Northwest Territories. Bulletin of Canadian Petroleum Geology, 53: 200-209.

Lenz, A.C., and Pedder, A.E.H. 1972. Lower and Middle Paleozoic sediments and paleontology of Royal Creek and Peel River, Yukon, and Powell Creek, N.W.T., Field excursion A14, guidebook, XXIV International Geological Congress.

Mackenzie, W.S. 1972: Fibrous calcite, a Middle Devonian geologic marker with stratigraphic significance, District of Mackenzie, Northwest Territories; Canadian Journal of Earth Sciences, 9: 1431-1440.

Meijer-Drees, N.C. 1993. The Devonian succession in the subsurface of the Great Slave and Great Bear Plains, Northwest Territories. Geological Survey of Canada, Bulletin 393.

Morrow, D.W. 2012. Devonian of the Northern Canadian Mainland Sedimentary Basin (a contribution to the Geological Atlas of the northern Canadian Mainland Sedimentary Basin); Geological Survey of Canada, Open File 6997. doi:10.4095/290970.

Morrow, D.W., and Geldsetzer, H.H.J. 1988. Devonian of the eastern Canadian Cordillera. In Devonian of the World, Proceedings of the Second International Symposium on the Devonian System, Volume I, Regional Syntheses. Edited by N. J. McMillian, A. F. Embry and D. J. Glass. Canadian Society of Petroleum Geologists, Memoir 14: 85-121. 
Muir, I.D. 1988 Devonian Hare Indian and Ramparts formations, Mackenzie Mountains, N.W.T.: Basin-fill, platform and reef development. Ph.D. Thesis, University of Ontario, Ottawa.

Muir, I., and Dixon, O.A. 1985. Devonian Hare Indian-Ramparts evolution, Mackenzie Mountains, NWT, basin-fill and platform-reef development. In Contributions to the geology of the Northwest Territories; Volume 2. Edited by J.A. Brophy, pp. 85-90.

Muir, I., Wong, P., and Wendte, J. 1984. Devonian Hare Indian - Ramparts (Kee Scarp) evolution, Mackenzie Mountains and subsurface Norman Wells, N.W.T.: Basin-fill and platform development. In Carbonates in Subsurface and Outcrop, Edited by L. Eliuk, J. Kaldi and N. Watts CSPG Core Conference, Oct. 18-19, 1984, pp.82-102.

Mutti, M., and Hallock, P. 2003, Carbonate systems along nutrient and temperature gradients: Some sedimentological and geochemical constraints. International Journal of Earth Sciences, 92: 465-475.

Norris, A.W. 1968. Reconnaissance Devonian stratigraphy of northern Yukon Territory and northwestern District of Mackenzie. Geological Survey of Canada, Paper 67-53.

Norris, A.W. 1985. Stratigraphy of Devonian outcrop belts in northern Yukon Territory and Northwest Territories, District of Mackenzie (Operation Porcupine area). Geological Survey of Canada, Memoir 410.

Norris, A.W. 1997. Chapter 7: Devonian. In Geology and Mineral and Hydrocarbon Potential of Northern Yukon Territory and Northwestern District of Mackenzie. Edited by D.K. Norris. Geological Survey of Canada, Bulletin 422, pp. 163-200. 
North American Commission on Stratigraphic Nomenclature, 2005. North American stratigraphic code; American Association of Petroleum Geologists, Bulletin 89(11), 1547-1591.

Pugh, D.C. 1983. Pre-Mesozoic geology in the subsurface of Peel River Map area, Yukon Territory and District of Mackenzie; Geological Survey of Canada, Memoir 401.

Pugh, D.C. 1993. Subsurface geology and pre-Mesozoic strata, Great Bear River map area, District of Mackenzie, Geological Survey of Canada, Memoir 430.

Pyle, L.J., Gal, L.P., and Lemiski, R.T. 2011. Measured sections and petroleum potential data (conventional and unconventional) of Horn River Group outcrops - Part 1, NTS 96D, 96E, and 106H, Northwest Territories; NWT Open File Report 2011-09.

Pyle, L.J., and Gal, L.P. 2012. Measured sections and petroleum potential data (conventional and unconventional) of Horn River Group outcrops, NTS 95M, 95N, 96C, 96D, 96E, 106H, and 106I, Northwest Territories - Part II; Northwest Territories Geoscience Office, NWT Open File Report 2012-008.

Pyle, L.J., and Gal, L.P. 2013. Measured sections and petroleum potential data (conventional and unconventional) of Horn River Group outcrops, NTS 96C, 96E, and 106H, Northwest Territories - Part III; Northwest Territories Geoscience Office, NWT Open Report 2013-005.

Pyle, L.J., Gal, L.P., and Fiess, K.M. 2014. Devonian Horn River Group: A reference section, lithogeochemical characterization, correlation of measured sections and wells, and petroleum-potential data, Mackenzie Plain area (NTS 95M, 95N, 96C, 96D, 96E, 
106H, and 106I), NWT; Northwest Territories Geoscience Office, NWT Open File Report 2014-06.

Pyle, L.J., Gal, L.P., and Hadlari, T. 2015. Thermal maturity trends for Devonian Horn River Group units and equivalent strata in the Mackenzie Corridor, Northwest Territories and Yukon. Geological Survey of Canada, Open File 7850.

Pyle, L.J., and Gal, L.P. 2016. Reference Section for the Horn River Group and Definition of the Bell Creek Member, Hare Indian Formation in central Northwest Territories, Bulletin of Canadian Petroleum Geology, 64((1):):67-98.

Rocheleau, J., and Fiess, K.M. 2014. Northwest Territories Oil and Gas Poster Series: Basins \& Petroleum Resources, Table of Formations, Schematic Cross Sections; Northwest Territories Geoscience Office, NWT Open File Report 2014-03.

Schlager, W. 1981. The paradox of drowned reefs and carbonate platforms. Geological Society of America Bulletin, 92: 197-211.

Schlager, W. 1999. Type 3 Sequence Boundaries. In Advances in Carbonate Sequence Stratigraphy: Application to Reservoirs, Outcrops and Models. Edited by P.M., Harris, A.H., Saller and T. Simo, SEPM Special Publication, 63: 35-45.

Schlager W. 2003. Benthic carbonate factories of the Phanerozoic, International Journal of Earth Sciences, 92: 445-464.

Stewart, J.H. 1945. Recent exploratory deep drilling in Mackenzie River valley, Northwest Territories; Geological Survey of Canada, Paper 45-29.

Tassonyi, E.J. 1969. Subsurface geology, lower Mackenzie River and Anderson River area, District of Mackenzie; Geological Survey of Canada, Paper 68-25. 
Taylor, A., Goldring, R., and Gowland, S. 2003. Analysis and application of ichnofabrics; Earth-Science Reviews, 60: 227-259.

Tribovillard, N., Algeo, T., Lyons, T.W., Riboulleau, A. 2006. Trace metals as paleoredox and paleoproductivity proxies: an update. Chemical Geology, 232: 12-32.

Uyeno, T.T. 1978. Devonian conodont biostratigraphy of Powell Creek and adjacent areas, western District of Mackenzie. In Western and Arctic Canadian Biostratigraphy. Edited by C.R. Stelck and B.D.E. Chatterton. Geological Association of Canada Special Paper, 18: 233-257.

Uyeno, T.T. 1986. Report on 177 conodont samples from the Hume, Hare Indian, Ramparts (Kee Scarp) and Canol formations from 12 Sections at Mountain River and Vicinity, Mackenzie Mountains, District of Mackenzie (NTS 106H), submitted by Iain Muir, Department Of Geology, University Of Ottawa; Geological Survey of Canada, Paleontological Report 1-TTU-86.

Uyeno, T.T. 2008. Report on ten Devonian conodont samples from Northern Mackenzie Mountains, collected for the Peel Petroleum Project, submitted by Dr. Leanne Pyle, Geological Survey Of Canada - Pacific, NTS 106G, H. Con. No. 1719; Geological Survey of Canada, Paleontological Report 1-TTU-2008.

Walliser, O., and Bultynck, P. 2011. Extinctions, survival and innovations of conodont species during the Kačák Episode (Eifelian-Givetian) in south-eastern Morocco. Bulletin de l'Institut Royal des Sciences Naturelles de Belgique, Sciences de la Terre, 81: 5-25. 
Wedepohl, K.H. 1971. Environmental influences on the chemical composition of shales and clays. In Physics and Chemistry of the Earth. Edited by Ahrens, L.H., Press, F., Runcorn, S.K., Urey, H.C., Pergamon, Oxford, pp. 305-333.

Wedepohl, K.H. 1991. The composition of the upper Earth's crust and the natural cycles of selected metals. In Metals and their Compounds in the Environment. Edited by E. Merian, VCH-Verlagsgesellschaft, Weinheim, pp. 3-17.

Whittaker, E.J. 1922. Mackenzie River district between Great Slave Lake and Simpson. In Geological Survey of Canada, Summary Report for 1921, Pt. B., pp. 45-55.

Wilkin, R.T., Barnes, H.L., and Brantley, S.L. 1996. The size distribution of framboidal pyrite in modern sediments: an indicator of redox conditions. Geochimica et Cosmochimica Acta, 60: 3897-3912.

Williams, G.K. 1983. What does the term "Horn River Formation" mean? Bulletin of Canadian Petroleum Geology, 31: 117-122.

Yose, L.A., Brown, S., Davis, T.L., Eiben, T., Kompanik, G.S. and Maxwell, S.R. 2001. 3-D geologic model of a fractured carbonate reservoir, Norman Wells Field, NWT, Canada. Bulletin of Canadian Petroleum Geology, 49: 86-116.

\section{TABLES}

Table 1. Well log signatures of lithostratigraphic units in five new exploration wells drilled to the south of Norman Wells, described as median value \pm standard deviation. 
Table 2. Well log signatures of lithostratigraphic units in six relatively recent wells from Norman Wells Oilfield and northwestern part of the study area, described as median value \pm standard deviation. $(*)$ Intervals assigned to Canyon Member are excluded.

\section{FIGURES}

Fig. 1. Study area. (A) A digital elevation model with lines of cross-sections from figures 3-6. Distribution of Horn River Group to the North of $64^{\circ} 30^{\prime}$ is outlined by white. Inside this area, two major facies zones are the northern area (shaded by yellow) with the Bell Creek Member and the Ramparts Formation and the southern off-bank area (SOB) where these units are absent. (B) Location of the study area on the index map of Canada, (C) Location of the study area on the paleogeographic basemap for Givetian Time (385 Ma), courtesy of Colorado Plateau Geosystems Inc.

Fig. 2. Lithostratigraphy of Horn River Group of Mackenzie Valley within NTS map areas 96C to 96E (Kabanov et al., 2016a,b) in comparison to previous lithostratigraphic correlations. Subdivision of Ramparts Formation is simplified.

Fig. 3. Cross-section A-A'. 'AL. Mb.' stands for the informal allochthonous limestone member; FR. CK. for the Francis Creek Member; RES for resistivity. The cross-sections on Figs. 3-6 are line-traced on Fig. 1.

Fig. 4. Cross-section B-B'.

Fig. 5. Cross-section C-C'.

Fig. 6. Cross-section D-D'. 
Fig. 7. Hume-Bluefish contact: (A-C) Overlapping core photos from Little Bear N-09 well; $(\mathrm{Hm})$ is the uppermost Hume bed with hardground, overprinting burrowing fabric, and corroded macrofossils (black arrows), $(B l l)$ is the basal Bluefish tentaculitid grainstone, and $(B l 2)$ is the overlying black calcareous shale; the shale seam at the Hume/Bluefish contact is preserved only in small pockets (white arrow); (D) same contact at Francis Creek; unit 4 is the uppermost Hume bed, unit 5 is the basal Bluefish limestone, and unit 6 is the Bluefish black shale with large pre-compactional calcareous nodules $(p c n)$.

Fig. 8. Mudrocks in cores at hand-lens magnification. (A,B) siliceous mudrocks of Canol Fm. on slabbed core face: note pyritic streaks and laminae in $(\mathrm{A}) ;(r c h)$ is radiolarite chertstone; $(r s h)$ is red pyritized shale seam; arrows in (B) point at calcite-cemented joints; (A) Loon Creek O-06, 1695.2 m; (B) same well, 1694.6 m. (C) Fissile aspect of Mirror Lake member in the type section, $1647.4 \mathrm{~m}$. (D) Zoomed-in image of pyriticp streak in Canol mudrock. (E) Typical pyritic nodule in dark mudrock of lower Loon Creek Member, Little Bear N-09, 1672.2 m. (F) Siliceous sponge spicules on bedding plane, Loon Creek Member, Mirror Lake N-20, 1911.9 m. (G) Pyritic tablets (pyritized acritarchs) on bedding plane, Mirror Lake Member, Loon Creek O-06, 1656.85 m. (H) Heterolithic laminated siltstone to mudrock characteristic of Canyon type B - upper Loon Creek interval, Mirror Lake N-20 well, 1912.95 m. (I) Typical flaky texture of grey fissile shale on bedding planes, Francis Creek Member, 1789.6 m MD, Loon Creek O-06.

Fig. 9. Canyon Creek G-51 section and its correlation: (A) type section for Canyon Member in Canyon Creek G-51 well; simplified lithology of shales and siltstones is shown with grey shades on a cored interval. 
Fig. 10. Chemostratigraphy and pyrolysis logs for Little Bear N-09 and Loon Creek O-06 wells.

Fig. 11. XRD data and geochemical expression of carbonates and pyrites in Little Bear N-09 well.

Fig. 12. Summary of conodont distribution in the Horn River Group. Data used in this figure are from Powell Creek (Uyeno 1978, 1-TTU 1986, 1 unpublished sample) Rumbly Creek (1-TTU-2008) and new data from cores and outcrops (Kabanov et al., 2016a; Gouwy, 2016a, 2016b). Conodont zonation after Kaufmann 2006, absolute dates from the International Stratigraphic Chart 2015 (Cohen et al., 2013).

Fig. 13. Conodont plate.

A. Polygnathus amphora Walliser \& Bultynck 2011, upper view, GSC loc. c-549917, Hare Indian Formation, Dodo Canyon, GSC136553

B. Ozarkodina semialternans (Wirth 1967), lateral view, GSC loc. c-597422, Hare Indian Formation, Prohibition Creek, GSC136554

C. Polygnathus angustidiscus Youngquist 1945, upper view, GSC loc. c-597453, Hare Indian Formation, Prohibition Creek, GSC136555

D. Polygnathus aff. P. pseudoeiflius Walliser \& Bultynck 2011, upper view, GSC loc. c549917, Hare Indian Formation, Dodo Canyon, GSC136556

E. Polygnathus ensensis Ziegler \& Klapper 1976, oblique-upper view, GSC loc. c473008, Hare Indian FormationFormation, Blue Fish MemberMember, Rumbly Creek, GSC136557 
F. Polygnathus linginguiformis sp. A. Uyeno \& Bultynck 1993, upper view, GSC loc. c473009, Hume FormationFormation, Rumbly Creek, GSC136558

G.\& K. Klapperina disparilis Ziegler \& Klapper 1976, lower and upper view, GSC loc. c-12170, Canol Formation, Powell Creek, GSC136559

H.\& L. Ancyrodella alata Glenister \& Klapper 1966, lower and upper view, GSC loc. c597452, Canol Formation, Prohibition Creek, GSC136560

I. Mesotaxis falsiovalis Sandberg, Ziegler \& Bultynck 1989/ Klapperina ovalis (Ziegler \& Klapper 1964), lower view, Norman Wells Core 755.81m, lowermost part of the Canol Formation (conodont in core)

J. Mesotaxis falsiovalis Sandberg, Ziegler \& Bultynck 1989/ Klapperina ovalis (Ziegler \& Klapper 1964), lower view, Mackenzie River core 398.25m, Canol Formation (conodont in core)

M. Palmatolepis transitans Müller 1956, AH 2C Kee Scarp Quarry, Ramparts Formation, GSC136561

N. Palmatolepis transitans Müller 1956 transitional to Palmatolepis punctata (Hinde 1879), AH 2C Kee Scarp Quarry, GSC136562

O. Palmatolepis punctata (Hinde 1879), lower view, Mackenzie River core, $398.25 \mathrm{~m}$, Canol Formation (conodont in core) 


\begin{tabular}{|c|c|c|c|c|c|c|}
\hline \multicolumn{2}{|c|}{$\begin{array}{l}\text { Lithostratigraphic } \\
\text { member }\end{array}$} & $\begin{array}{c}\text { Loon Creek } \\
\text { 0-06 }\end{array}$ & $\begin{array}{l}\text { Mirror Lake } \\
\quad \mathrm{N}-20\end{array}$ & $\begin{array}{l}\text { Little Bear } \\
\quad \mathrm{N}-09\end{array}$ & $\begin{array}{c}\text { Little Bear } \\
\text { H-64 }\end{array}$ & $\begin{array}{c}\text { East Mackay } \\
\text { I-78 }\end{array}$ \\
\hline \multicolumn{2}{|c|}{ Year drilled to TD and logged } & 2013 & 2013 & 2012 & 2012 & 2013 \\
\hline Basal Imperial & SGR, (gAPI) & $114 \pm 2.3$ & $117 \pm 3.5$ & $105 \pm 3.4$ & $110 \pm 3.2$ & $103 \pm 20.6$ \\
\hline Basal Imperial & CGR, (gAPI) & $92 \pm 2.6$ & $93 \pm 4.6$ & $99 \pm 6.9$ & $91 \pm 4.4$ & $67 \pm 11$ \\
\hline Basal Imperial & DTC, $(\mu \mathrm{S} / \mathrm{m})$ & $278 \pm 6.1$ & $276 \pm 4.8$ & $278 \pm 7.6$ & $281 \pm 9.2$ & $270 \pm 29.8$ \\
\hline Basal Imperial & M2RX, M2R9 (Ohm*m) & N/A & N/A & $6 \pm 0.8$ & $7 \pm 1.7$ & $7 \pm 2.1$ \\
\hline Canyon & SGR, (gAPI) & $20.4 \pm 124$ & $109 \pm 17.6$ & $95 \pm 13.9$ & $103 \pm 12.6$ & $84 \pm 10.6$ \\
\hline Canyon & CGR, (gAPI) & $72 \pm 12.4$ & $82 \pm 11.4$ & $91 \pm 16.9$ & $81 \pm 11.9$ & $59 \pm 9.9$ \\
\hline Canyon & $\mathrm{DTC},(\mu \mathrm{S} / \mathrm{m})$ & $291 \pm 11.7$ & $290 \pm 8.9$ & $285 \pm 12.9$ & $263 \pm 21.2$ & $249 \pm 7.9$ \\
\hline Canyon & M2RX, M2R9 (Ohm*m) & N/A & N/A & $8 \pm 7.7$ & $10 \pm 3$ & $10 \pm 1$ \\
\hline Loon Creek & SGR, (gAPI) & $124 \pm 17.5$ & $130 \pm 15.3$ & $122 \pm 13.6$ & $124 \pm 16.9$ & $113 \pm 21.9$ \\
\hline Loon Creek & CGR, (gAPI) & $66 \pm 8.2$ & $71 \pm 8.7$ & $74 \pm 11.5$ & $78 \pm 8.4$ & $74 \pm 9.2$ \\
\hline Loon Creek & DTC, $(\mu \mathrm{S} / \mathrm{m})$ & $285 \pm 9.3$ & $278 \pm 9.1$ & $287 \pm 6.8$ & $278 \pm 90.8$ & $291 \pm 7.2$ \\
\hline Loon Creek & M2RX, M2R9 (Ohm*m) & N/A & N/A & $12 \pm 52.4$ & $11 \pm 3.6$ & $8 \pm 4.6$ \\
\hline Mirror Lake & SGR, (gAPI) & $133 \pm 9$ & $131.2 \pm 15.5$ & $117 \pm 12.4$ & $117 \pm 12.2$ & $94 \pm 11.2$ \\
\hline Mirror Lake & CGR, (gAPI) & $79 \pm 8.6$ & $84 \pm 8.1$ & $86 \pm 7.5$ & $91 \pm 5.2$ & $66 \pm 8.5$ \\
\hline Mirror Lake & DTC, $(\mu \mathrm{S} / \mathrm{m})$ & $313 \pm 7.4$ & $303 \pm 9.2$ & $303 \pm 6.3$ & $310 \pm 5.4$ & $297 \pm 6.4$ \\
\hline Mirror Lake & M2RX, M2R9 (Ohm*m) & N/A & N/A & $5 \pm 1.5$ & $5 \pm 1$ & $5 \pm 1.1$ \\
\hline Dodo Canyon & SGR, (gAPI) & $161 \pm 33.1$ & $164 \pm 33.8$ & $154 \pm 120.4$ & $168 \pm 34.9$ & $179 \pm 42.9$ \\
\hline Dodo Canyon & CGR, (gAPI) & $35 \pm 9.8$ & $37 \pm 8.6$ & $39 \pm 11.8$ & $42 \pm 11.5$ & $48 \pm 16.3$ \\
\hline Dodo Canyon & DTC, $(\mu \mathrm{S} / \mathrm{m})$ & $261 \pm 10.5$ & $256 \pm 11.9$ & $259 \pm 13$ & $264 \pm 119.8$ & $264 \pm 18.1$ \\
\hline Dodo Canyon & M2RX, M2R9 (Ohm*m) & N/A & N/A & $77 \pm 42.8$ & $66 \pm 40.3$ & $39 \pm 55.2$ \\
\hline Vermillion Creek & SGR, (gAPI) & $156 \pm 35.9$ & $170 \pm 39.0$ & $164 \pm 41$ & $177 \pm 38.2$ & $203 \pm 41.3$ \\
\hline Vermillion Creek & CGR, (gAPI) & $47 \pm 9.9$ & $52 \pm 8.3$ & $53 \pm 11.5$ & $59 \pm 10.3$ & $61 \pm 13.2$ \\
\hline Vermillion Creek & DTC, $(\mu \mathrm{S} / \mathrm{m})$ & $254 \pm 9.8$ & $256 \pm 8.7$ & $257 \pm 8.8$ & $259 \pm 10.1$ & $264 \pm 7.6$ \\
\hline Vermillion Creek & M2RX, M2R9 $(\mathrm{Ohm} * \mathrm{~m})$ & N/A & N/A & $84 \pm 76.2$ & $150 \pm 119$ & $124 \pm 163.2$ \\
\hline Prohibition Creek & SGR, (gAPI) & $142 \pm 23$ & $148 \pm 26.2$ & $138 \pm 24$ & $135 \pm 20.8$ & $128 \pm 21.8$ \\
\hline Prohibition Creek & CGR, (gAPI) & $35 \pm 7.4$ & $40 \pm 5.5$ & $45 \pm 8.9$ & $51 \pm 12.3$ & $52 \pm 12.5$ \\
\hline Prohibition Creek & DTC, $(\mu \mathrm{S} / \mathrm{m})$ & $265 \pm 4.6$ & $266 \pm 9.8$ & $264 \pm 7$ & $262 \pm 114.3$ & $269 \pm 9.9$ \\
\hline Prohibition Creek & M2RX, M2R9 (Ohm*m) & N/A & N/A & $65 \pm 26.8$ & $63 \pm 35.6$ & $31 \pm 25.3$ \\
\hline Francis Creek & SGR, (gAPI) & $130 \pm 25.8$ & $133 \pm 9.7$ & $127 \pm 16.5$ & $139 \pm 8.9$ & $119 \pm 5.6$ \\
\hline Francis Creek & CGR, (gAPI) & $78 \pm 12.7$ & $94 \pm 5.5$ & $83 \pm 11.3$ & $90 \pm 6$ & $80 \pm 6.5$ \\
\hline Francis Creek & DTC, $(\mu \mathrm{S} / \mathrm{m})$ & $282 \pm 18$ & $296 \pm 3.6$ & $294 \pm 8.9$ & $284 \pm 6.4$ & $291 \pm 4.3$ \\
\hline Francis Creek & M2RX, M2R9 (Ohm*m) & N/A & N/A & $12 \pm 4.7$ & $15 \pm 3$ & $6 \pm 1$ \\
\hline Bluefish & SGR, (gAPI) & $185 \pm 56.7$ & $192 \pm 47.6$ & $172 \pm 50.9$ & $188 \pm 58.2$ & $181 \pm 72.3$ \\
\hline Bluefish & CGR, (gAPI) & $53 \pm 20.7$ & $67 \pm 14.6$ & $68 \pm 18.9$ & $76 \pm 14.5$ & $64 \pm 13.1$ \\
\hline Bluefish & DTC, $(\mu \mathrm{S} / \mathrm{m})$ & $280 \pm 26.9$ & $293 \pm 23.0$ & $295 \pm 26.9$ & $263 \pm 21.2$ & $272 \pm 19.9$ \\
\hline Bluefish & M2RX, M2R9 (Ohm*m) & N/A & N/A & $30 \pm 44.9$ & $61 \pm 35$ & $34 \pm 21.6$ \\
\hline
\end{tabular}




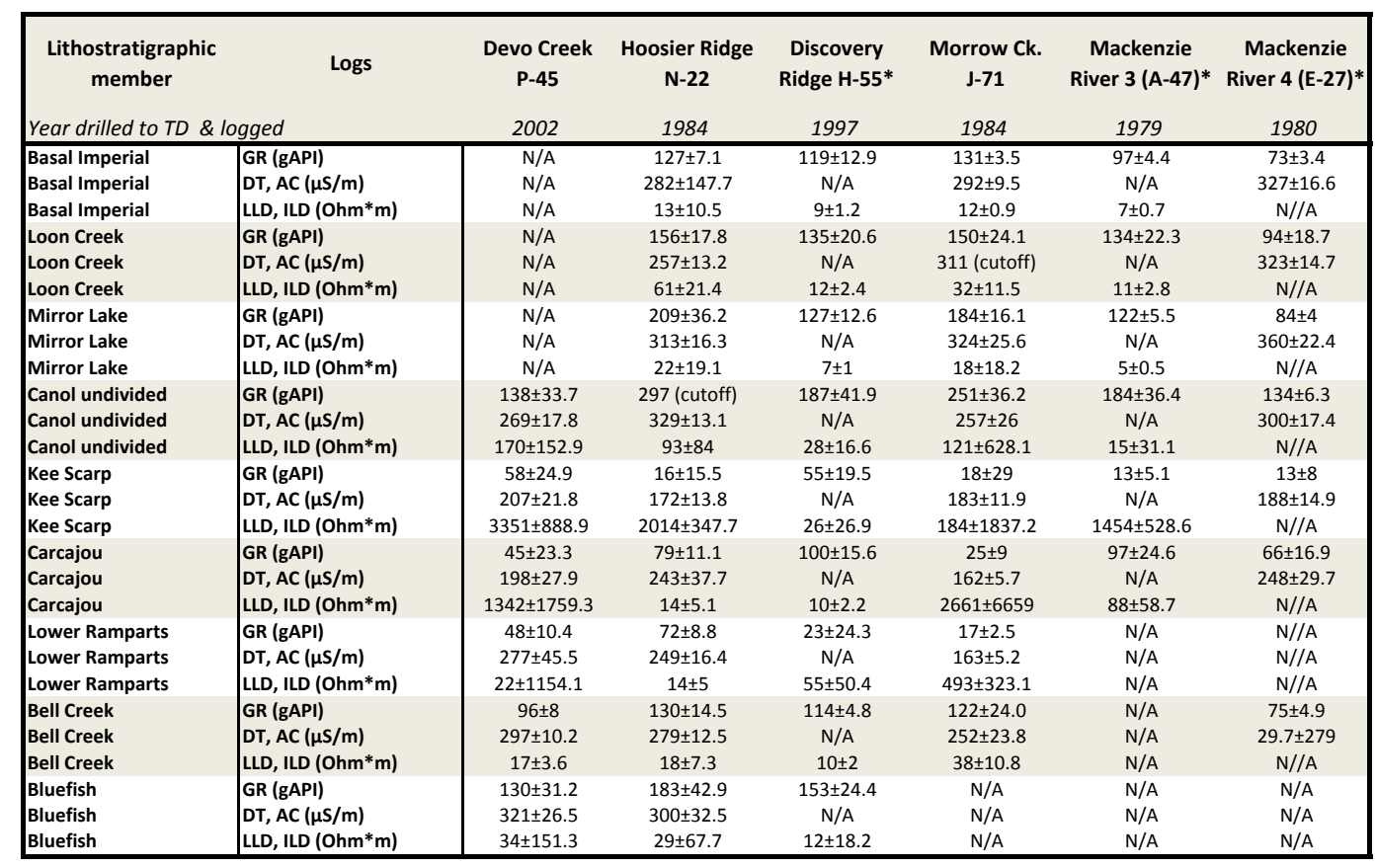




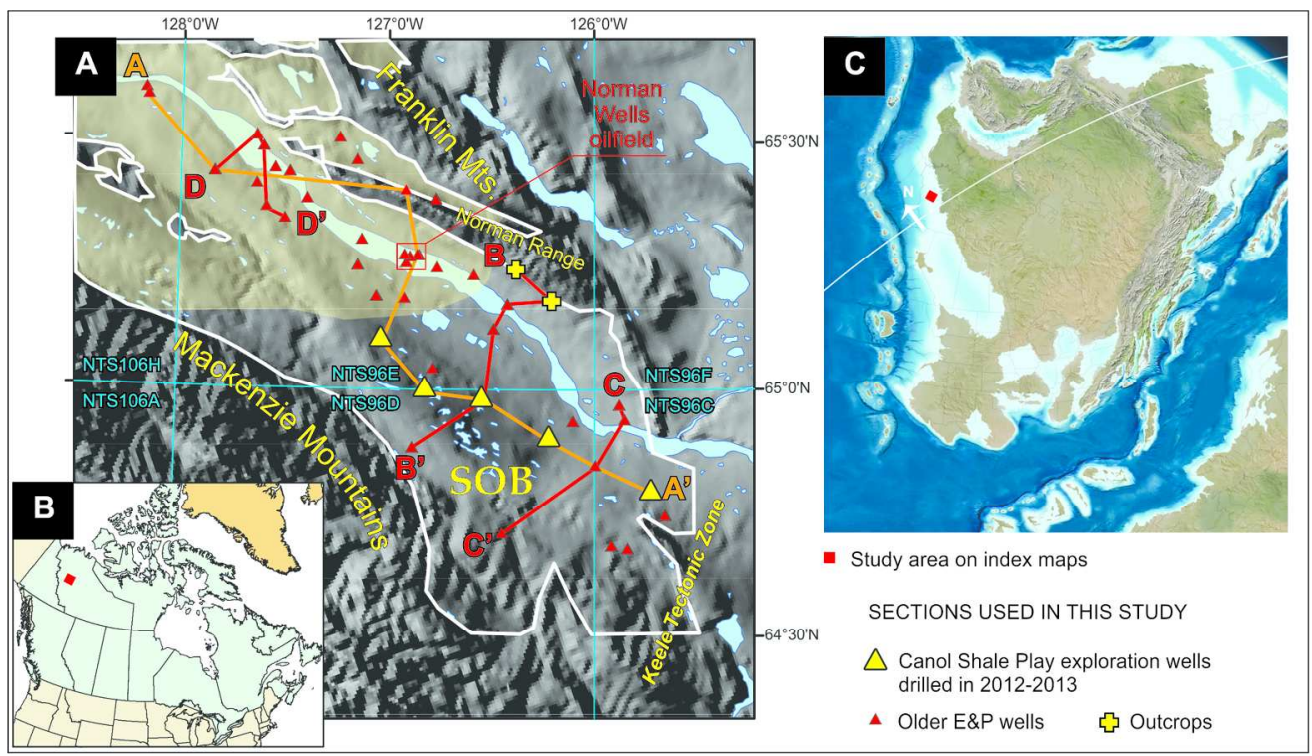

Fig. 1. Study area. (A) A digital elevation model with lines of cross-sections from figures 3-6. Distribution of Horn River Group to the North of $64^{\circ} 30^{\prime}$ is outlined by white. Inside this area, two major facies zones are the northern area (shaded by yellow) with the Bell Creek Member and the Ramparts Formation and the southern off-bank area (SOB) where these units are absent. (B) Location of the study area on the index map of Canada, (C) Location of the study area on the paleogeographic basemap for Givetian time (385 Ma), courtesy of Ron Blakey (www2.nau.edu/rcb7, April 2016).

$180 \times 103 \mathrm{~mm}(300 \times 300 \mathrm{DPI})$ 


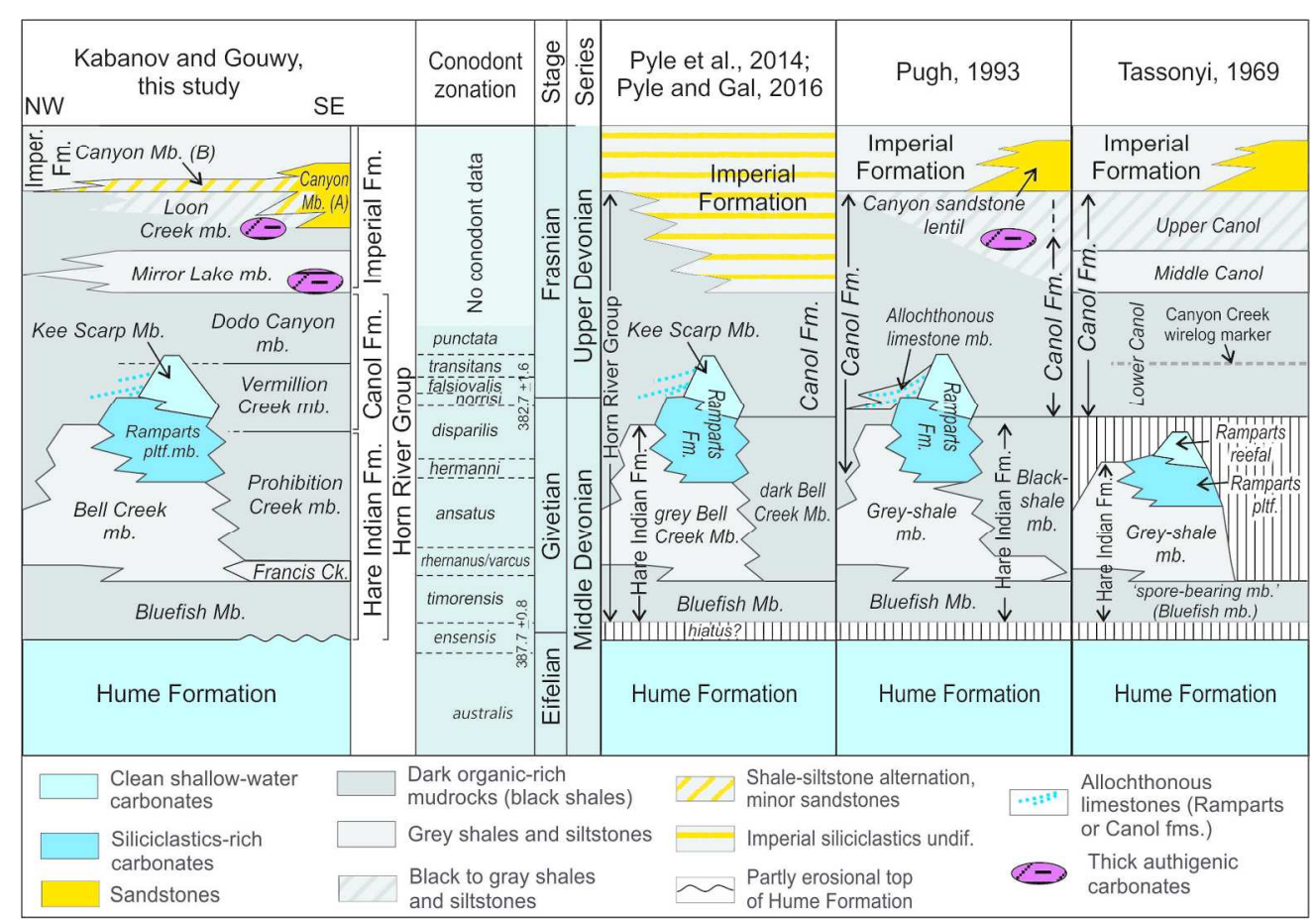

Fig. 2. Lithostratigraphy of Horn River Group of Mackenzie Valley within NTS map areas $96 \mathrm{C}$ to $96 \mathrm{E}$ (Kabanov et al., 2016a,b) in comparison to previous lithostratigraphic correlations. Subdivision of Ramparts Formation is simplified.

$180 \times 125 \mathrm{~mm}(300 \times 300 \mathrm{DPI})$ 


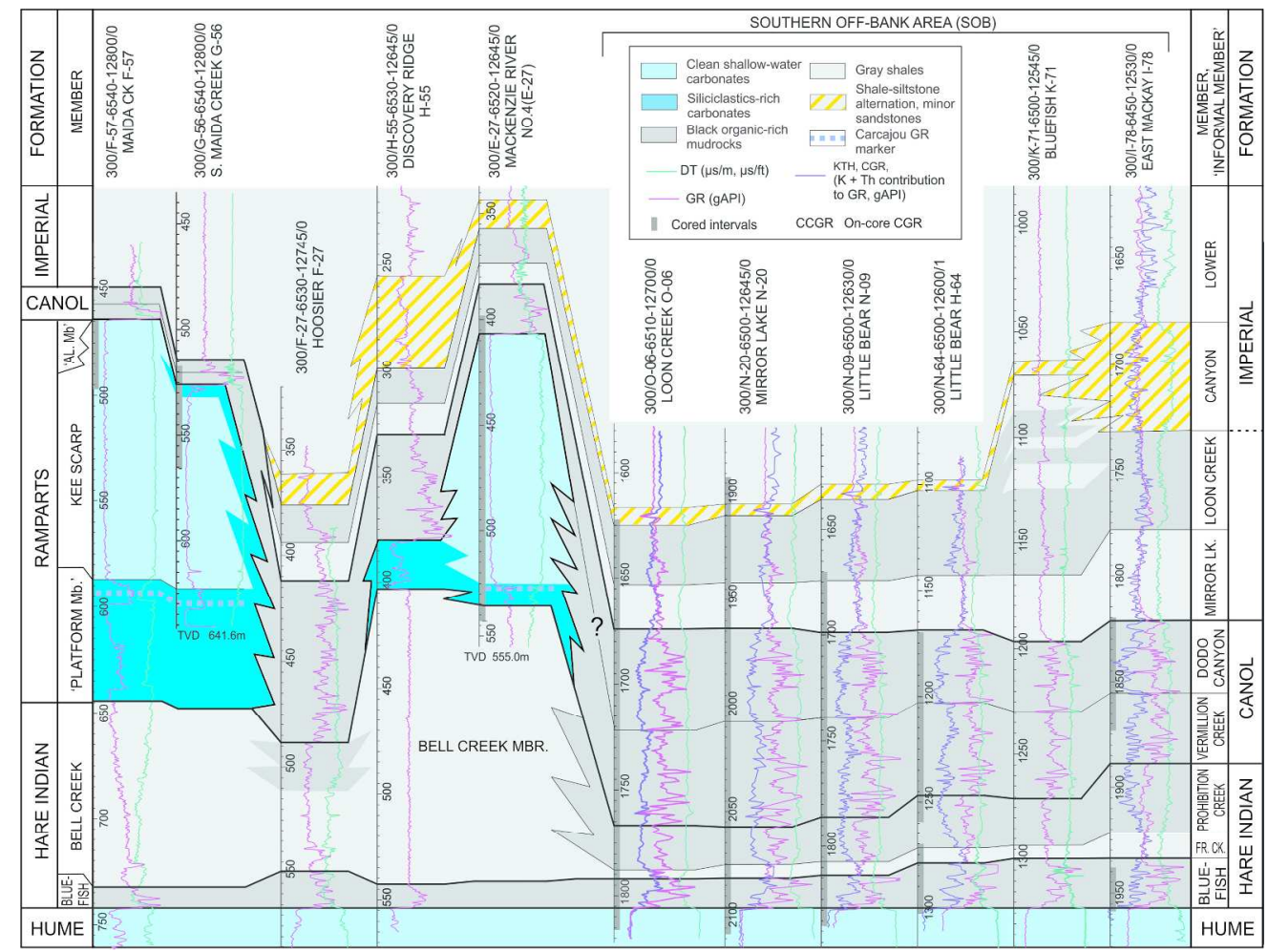

Fig. 3. Cross-section A-A'. 'AL. Mb.' stands for the informal allochthonous limestone member; FR. CK. for the Francis Creek Member; RES for resistivity. The cross-sections on Figs. 3-6 are line-traced on Fig. 1.

$238 \times 180 \mathrm{~mm}(300 \times 300 \mathrm{DPI})$ 


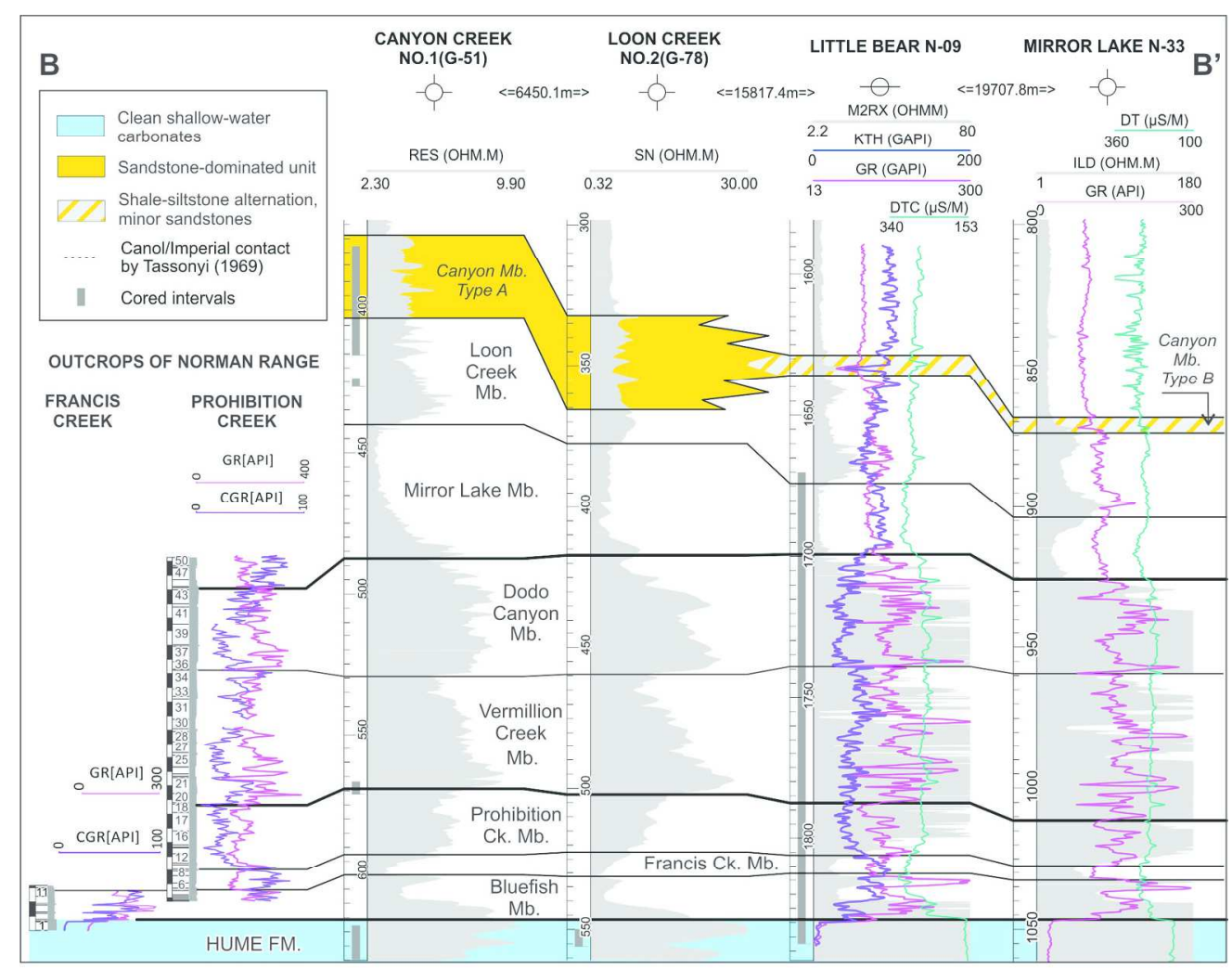

Fig. 4. Cross-section B-B'.

$176 \times 141 \mathrm{~mm}(300 \times 300 \mathrm{DPI})$ 


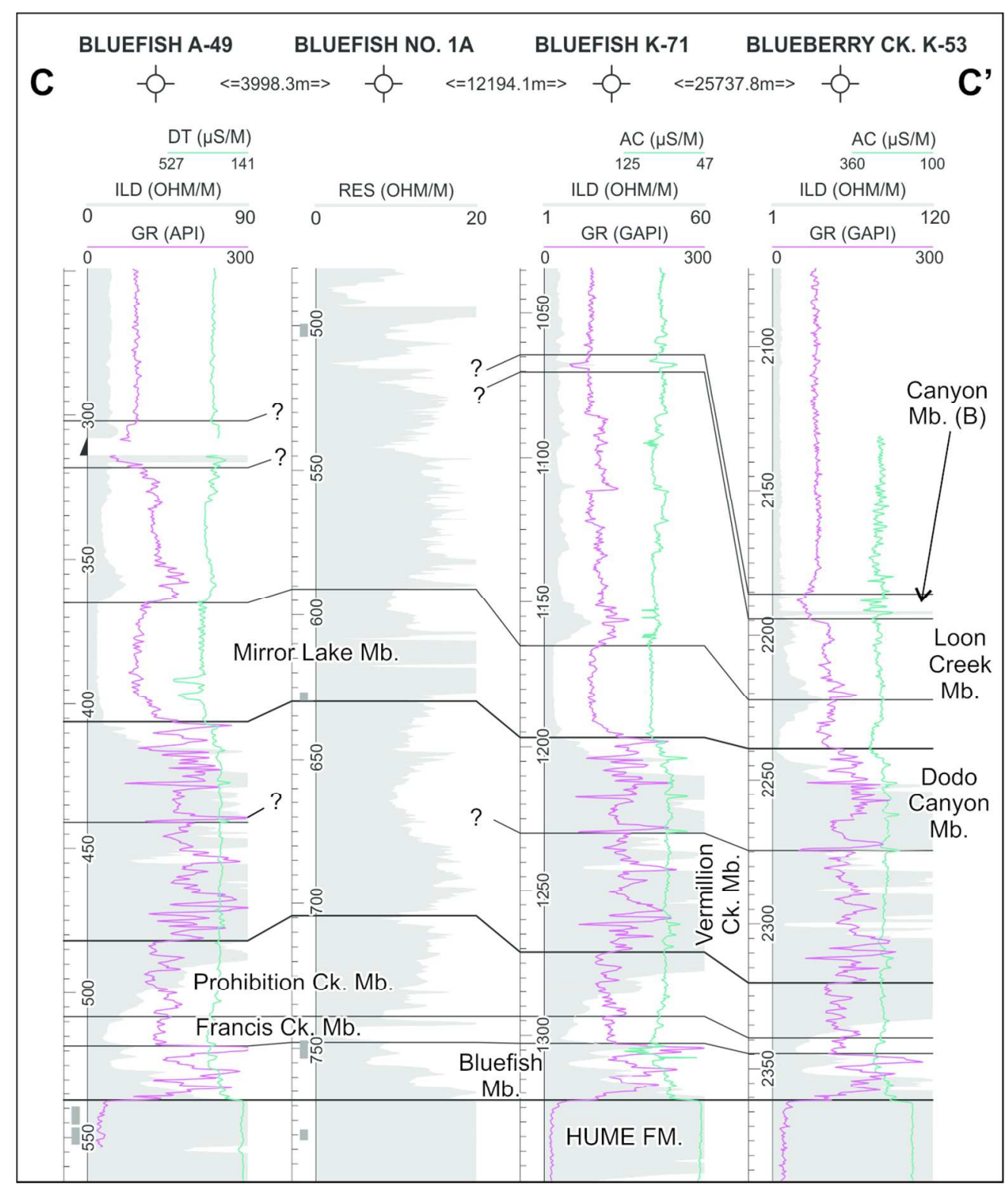

Fig. 5. Cross-section C-C'.

$117 \times 138 \mathrm{~mm}(300 \times 300 \mathrm{DPI})$ 


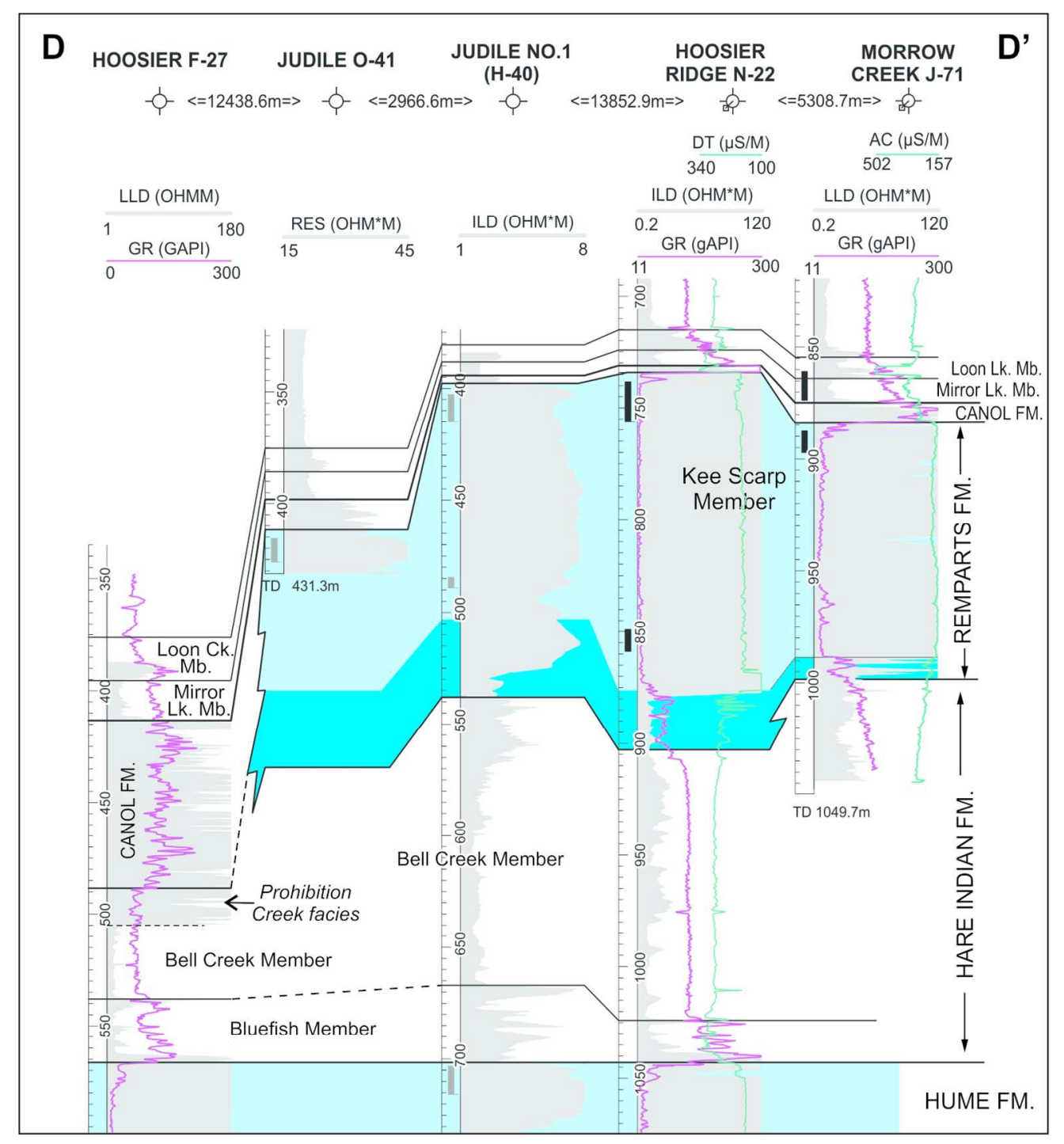

Fig. 6. Cross-section D-D'.

$130 \times 142 \mathrm{~mm}(300 \times 300 \mathrm{DPI})$ 

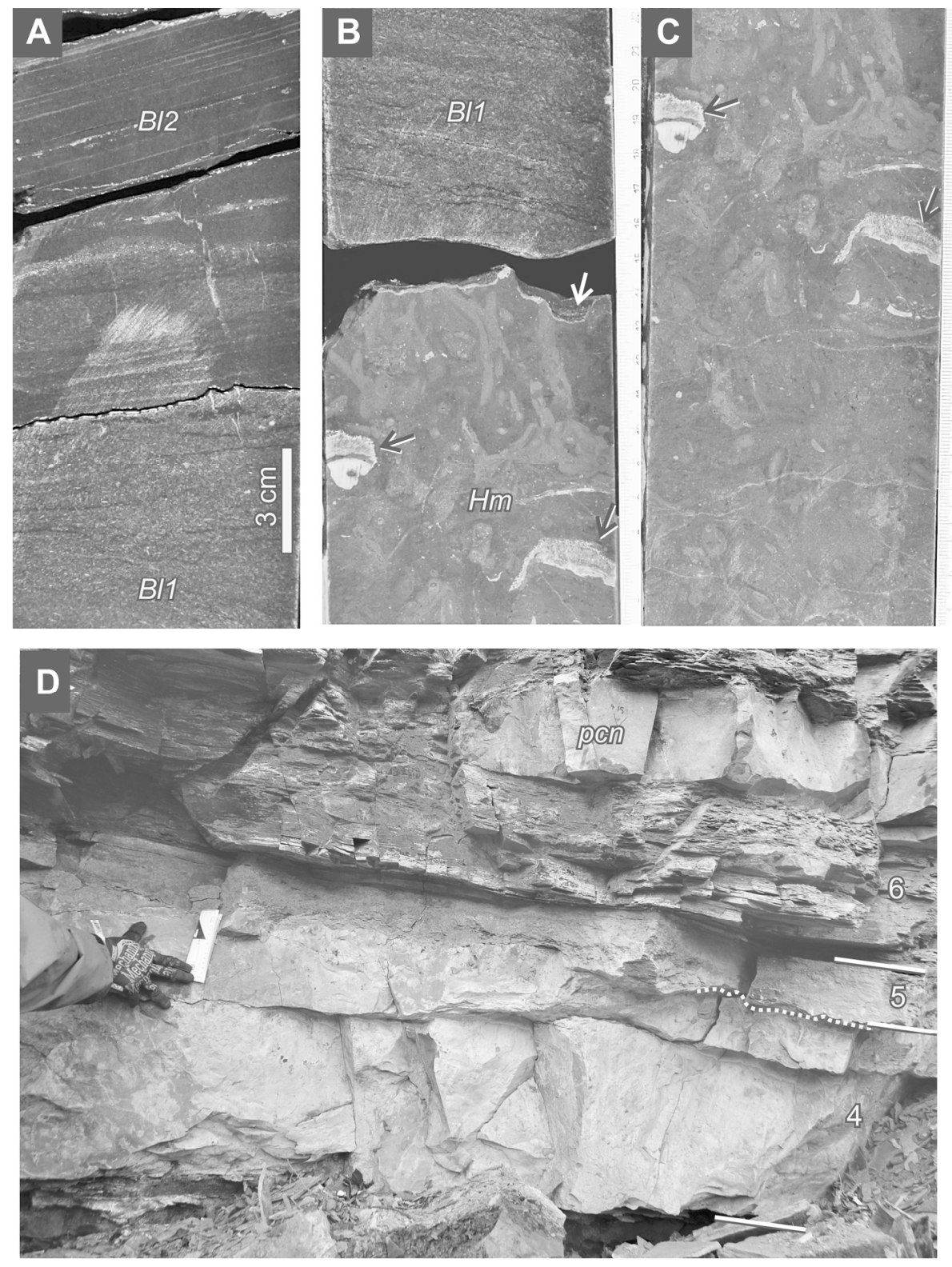

Fig. 7. Hume-Bluefish contact: (A-C) Overlapping core photos from Little Bear N-09 well; (Hm) is the uppermost Hume bed with hardground, overprinting burrowing fabric, and corroded macrofossils (black arrows), (BI1) is the basal Bluefish tentaculitid grainstone, and (BI2) is the overlying black calcareous shale; the shale seam at the Hume/Bluefish contact is preserved only in small pockets (white arrow); (D) same contact at Francis Creek; unit 4 is the uppermost Hume bed, unit 5 is the basal Bluefish limestone, and unit 6 is the Bluefish black shale with large pre-compactional calcareous nodules (pcn). 

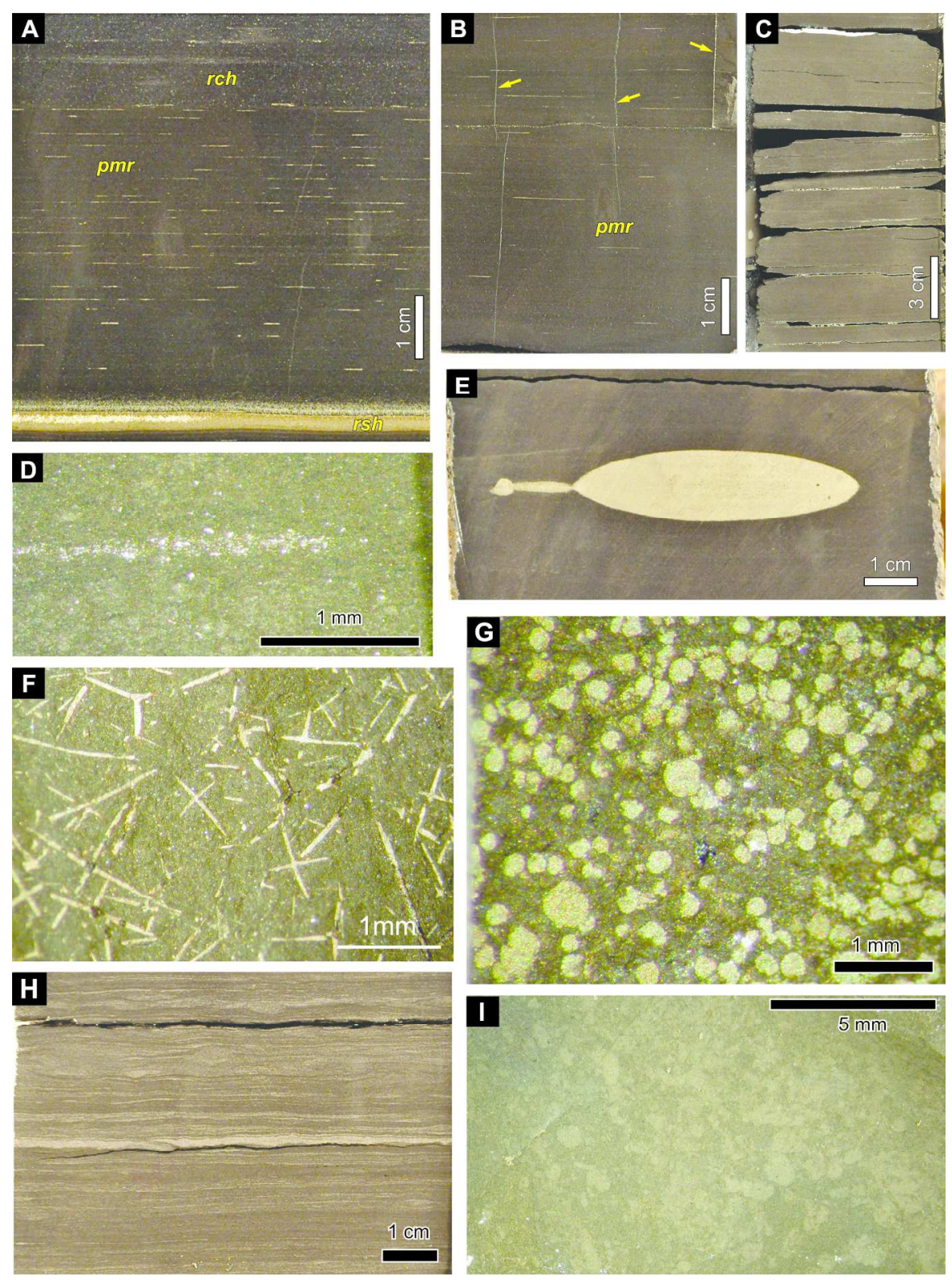

Fig. 8. Mudrocks in cores at hand-lens magnification. (A,B) siliceous mudrocks of Canol Fm. on slabbed core face: note pyritic streaks and laminae in $(A) ;(r c h)$ is radiolarite chertstone; $(r s h)$ is red pyritized shale seam; arrows in (B) point at calcite-cemented joints; (A) Loon Creek O-06, 1695.2 m; (B) same well, $1694.6 \mathrm{~m}$. (C) Fissile aspect of Mirror Lake member in the type section, $1647.4 \mathrm{~m}$. (D) Zoomed-in image of pyriticp streak in Canol mudrock. (E) Typical pyritic nodule in dark mudrock of lower Loon Creek Member, Little Bear N-09, $1672.2 \mathrm{~m}$. (F) Siliceous sponge spicules on bedding plane, Loon Creek Member, Mirror Lake $\mathrm{N}-20,1911.9 \mathrm{~m}$. (G) Pyritic tablets (pyritized acritarchs) on bedding plane, Mirror Lake Member, Loon Creek O-06, $1656.85 \mathrm{~m}$. (H) Heterolithic laminated siltstone to mudrock characteristic of Canyon type B - upper Loon Creek interval, Mirror Lake N-20 well, 1912.95 m. (I) Typical flaky texture of grey fissile shale on bedding planes, Francis Creek Member, 1789.6 m MD, Loon Creek O-06. 


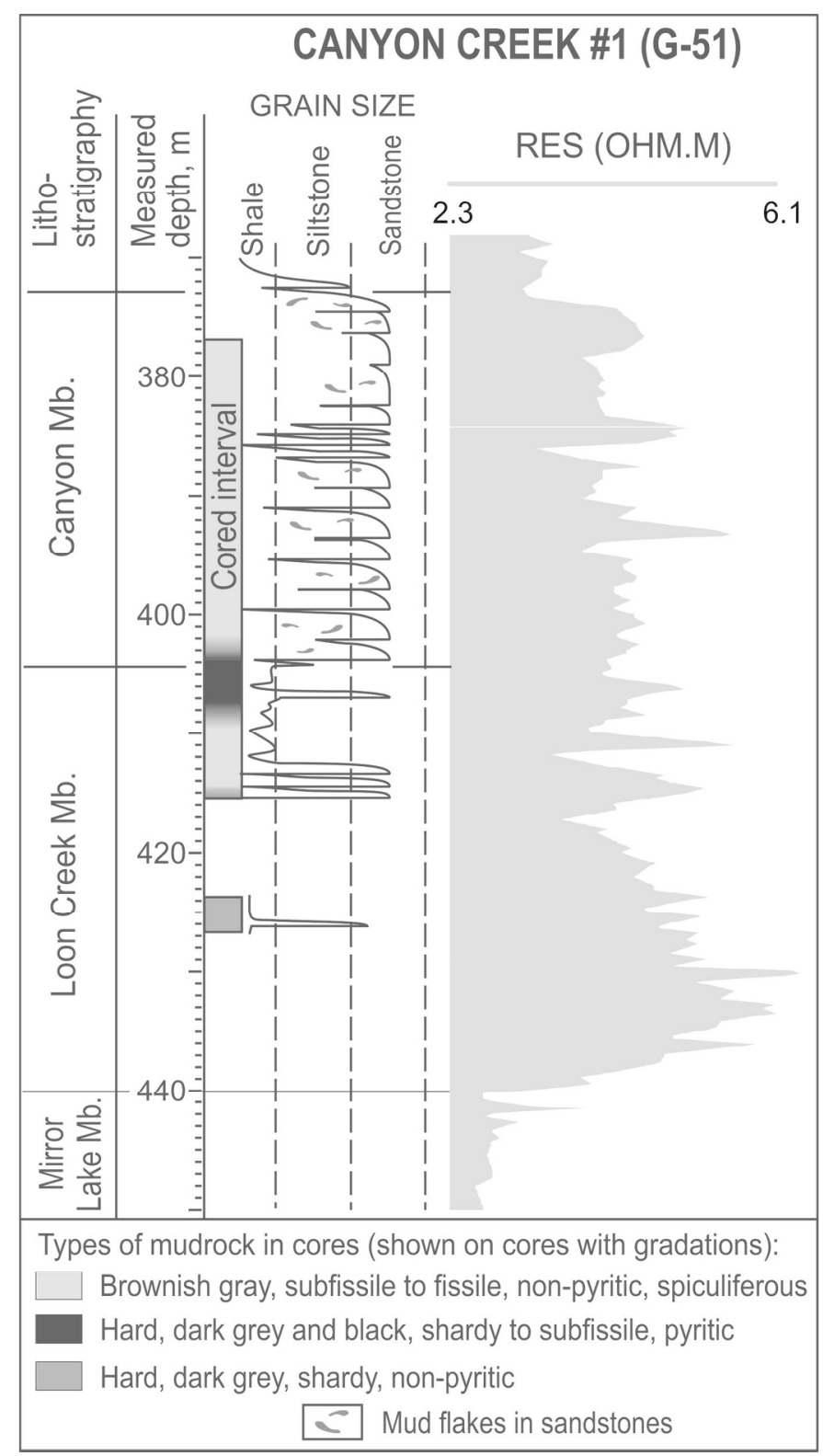

Fig. 9. Canyon Creek G-51 section and its correlation: (A) type section for Canyon Member in Canyon Creek G-51 well; simplified lithology of shales and siltstones is shown with grey shades on a cored interval.

$120 \times 216 \mathrm{~mm}(300 \times 300 \mathrm{DPI})$ 


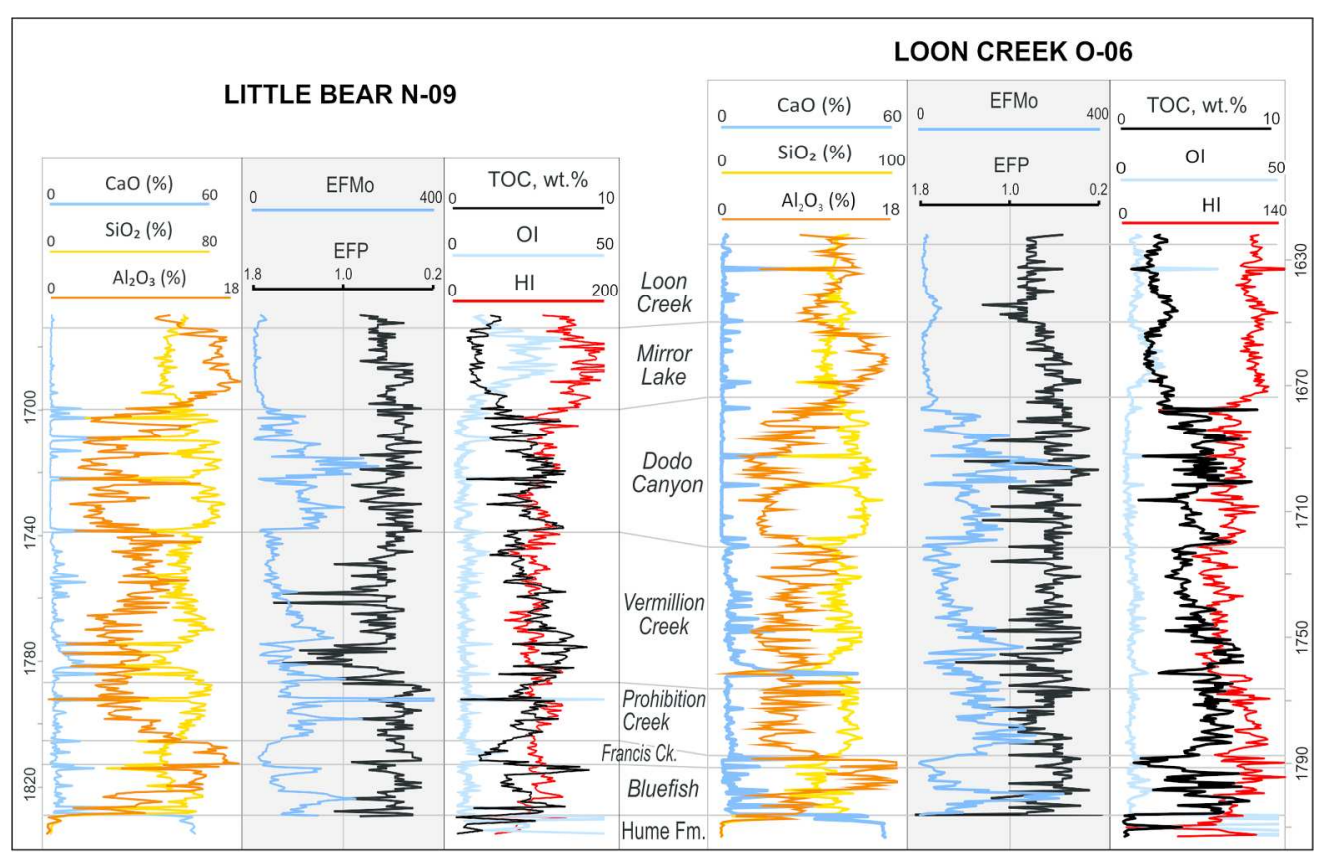

Fig. 10. Chemostratigraphy and pyrolysis logs for Little Bear N-09 and Loon Creek 0-06 wells. $176 \times 113 \mathrm{~mm}(300 \times 300 \mathrm{DPI})$ 


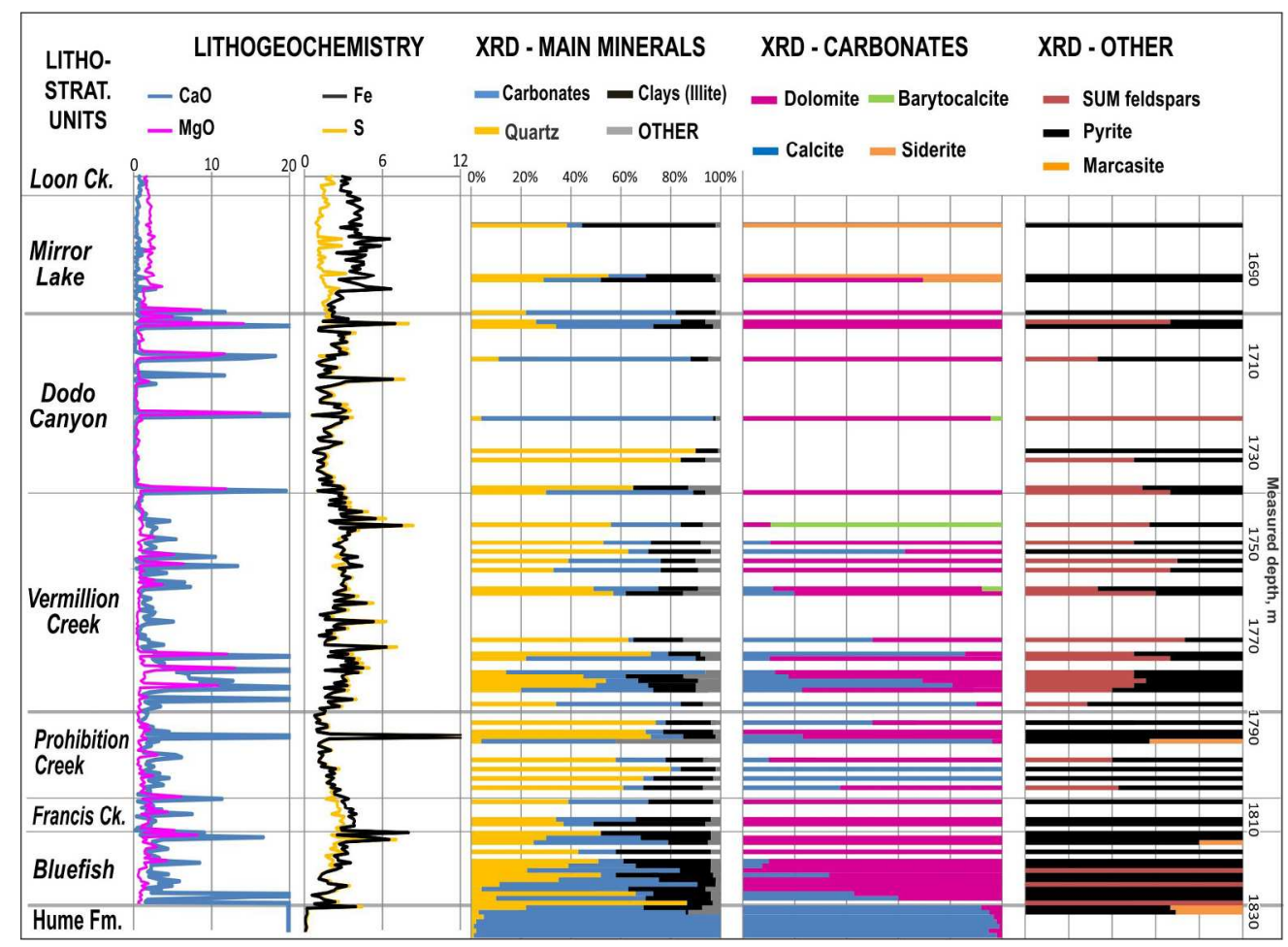

Fig. 11. XRD data and geochemical expression of carbonates and pyrites in Little Bear N-09 well. $180 \times 132 \mathrm{~mm}(300 \times 300 \mathrm{DPI})$ 


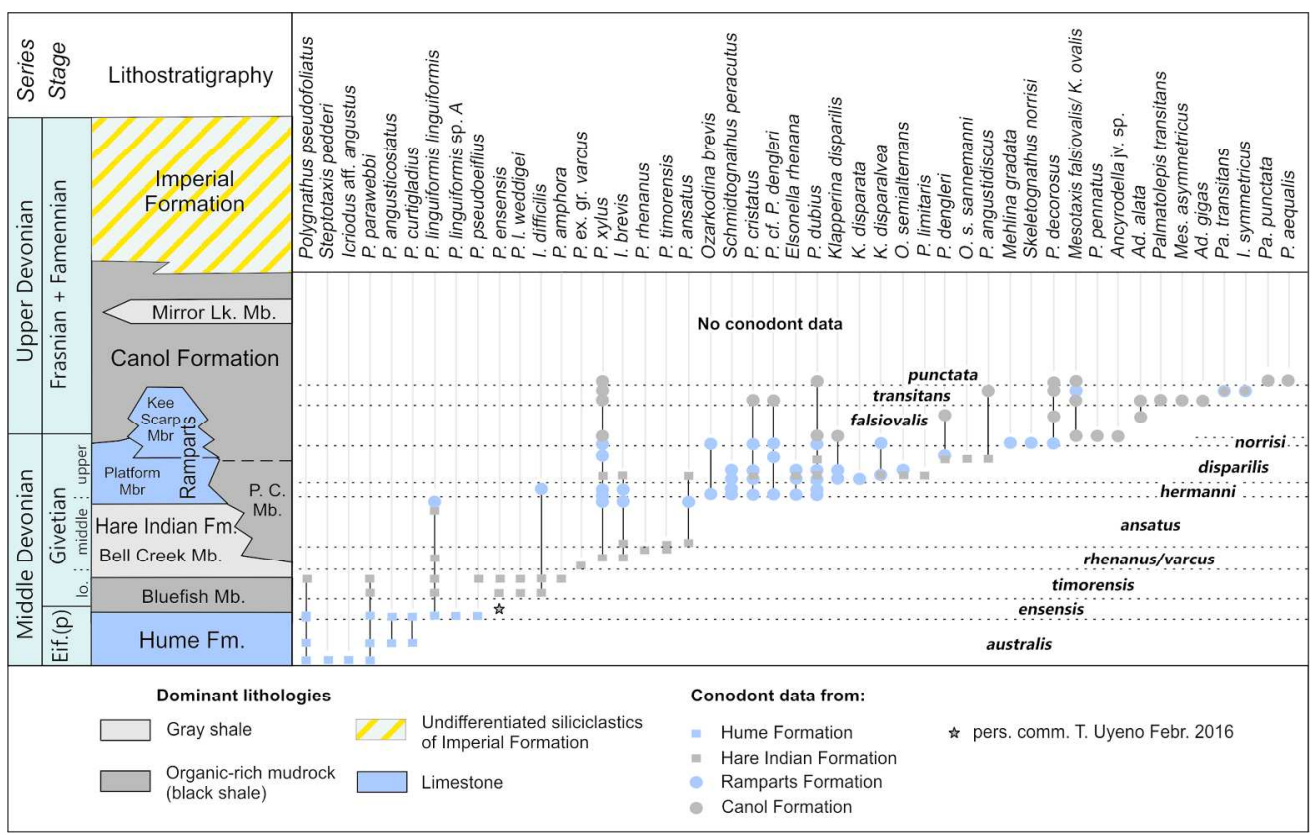

Fig. 12. Summary of conodont distribution in the Horn River Group. Data used in this figure are from Powell Creek (Uyeno 1978, 1-TTU 1986, 1 unpublished sample) Rumbly Creek (1-TTU-2008) and new data from cores and outcrops (Kabanov et al., 2016a; Gouwy, 2016a, 2016b). Conodont zonation after Kaufmann 2006, absolute dates from the International Stratigraphic Chart 2015 (Cohen et al., 2013).

$182 \times 114 \mathrm{~mm}(300 \times 300$ DPI $)$ 


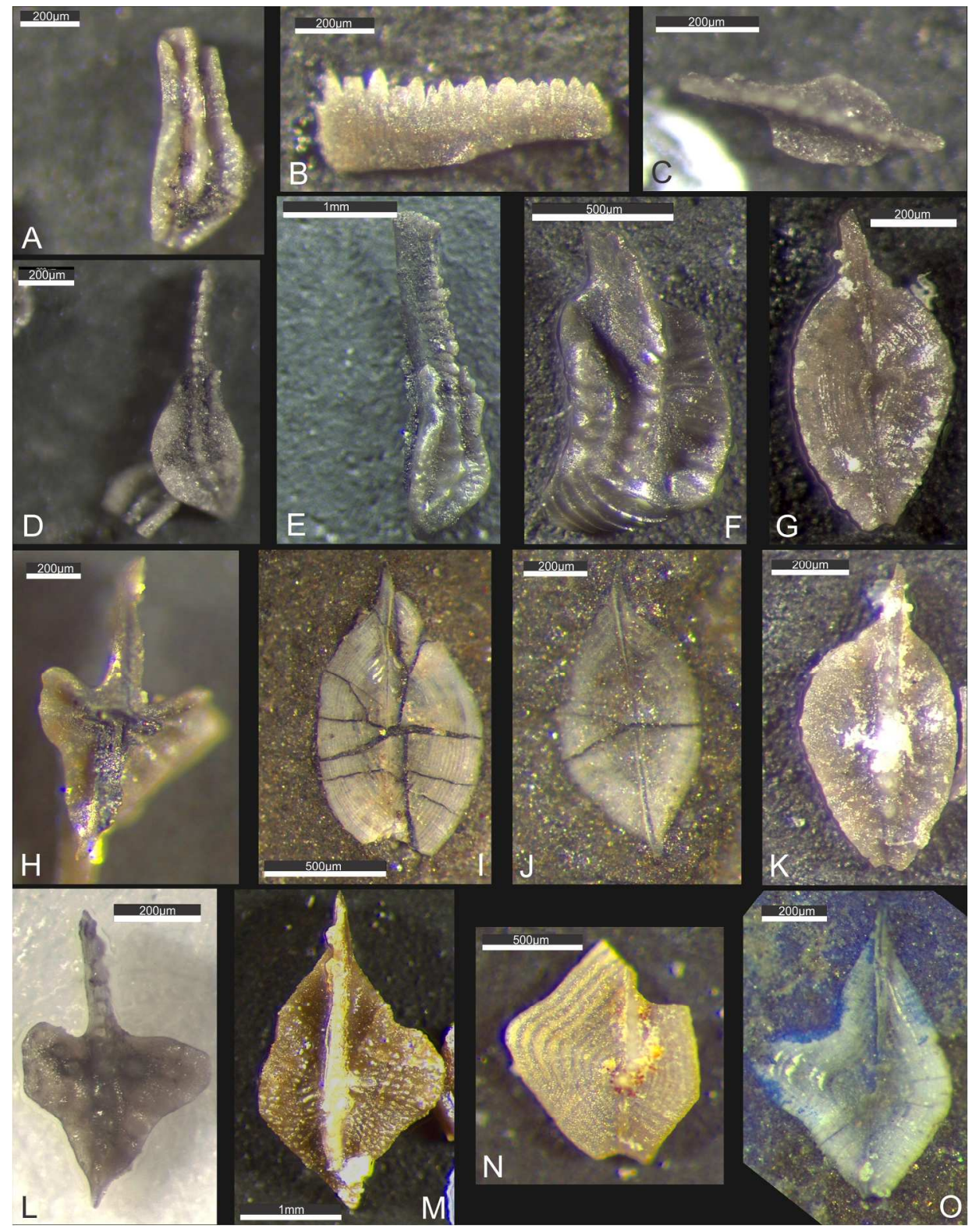

Fig. 13. Conodont plate. A. Polygnathus amphora Walliser \& Bultynck 2011, upper view, GSC loc. c-549917, Hare Indian Formation, Dodo Canyon, GSC136553; B. Ozarkodina semialternans (Wirth 1967), lateral view, GSC loc. c-597422, Hare Indian Formation, Prohibition Creek, GSC136554; C. Polygnathus angustidiscus Youngquist 1945, upper view, GSC loc. c-597453, Hare Indian Formation, Prohibition Creek, GSC136555; D. Polygnathus aff. P. pseudoeiflius Walliser \& Bultynck 2011, upper view, GSC loc. c-549917, Hare Indian Formation, Dodo Canyon, GSC136556; E. Polygnathus ensensis Ziegler \& Klapper 1976, oblique-upper view, GSC loc. c-473008, Hare Indian Formation, Blue Fish Member, Rumbly Creek, GSC136557; F. Polygnathus linginguiformis sp. A. Uyeno \& Bultynck 1993, upper view, GSC loc. c-473009, Hume Formation, Rumbly Creek, GSC136558; G.\& K. Klapperina disparilis Ziegler \& Klapper 1976, lower and upper view, GSC loc. c12170, Canol Formation, Powell Creek, GSC136559; H.\& L. Ancyrodella alata Glenister \& Klapper 1966, lower and upper view, GSC loc. c-597452, Canol Formation, Prohibition Creek, GSC136560; I. Mesotaxis falsiovalis Sandberg, Ziegler \& Bultynck 1989/ Klapperina ovalis (Ziegler \& Klapper 1964), lower view, Norman Wells Core 755.81m, lowermost part of the Canol Formation (conodont in core); J. Mesotaxis 
falsiovalis Sandberg, Ziegler \& Bultynck 1989/ Klapperina ovalis (Ziegler \& Klapper 1964), lower view, Mackenzie River core $398.25 \mathrm{~m}$, Canol Formation (conodont in core).

$180 \times 229 \mathrm{~mm}(300 \times 300 \mathrm{DPI})$ 